\title{
Late-glacial pollen and diatom changes in response to two different environmental perturbations: volcanic eruption and Younger Dryas cooling
}

\author{
A. F. Lotter ${ }^{1}$, H. J. B. Birks ${ }^{2}$ \& B. Zolitschka ${ }^{3}$ \\ ${ }^{I}$ Swiss Federal Institute for Environmental Science and Technology (EAWAG), CH-8600 Dübendorf, Switzerland, \\ and Geobotanik, Universität Bern, CH-3013 Bern, Switzerland \\ ${ }^{2}$ Botanical Institute, University of Bergen, Allégaten 41, N-5007 Bergen, Norway, and Environmental Change \\ Research Centre, University College London, 26 Bedford Way, London, WClH OAP, UK \\ ${ }^{3}$ Fachbereich VI, Geologie, Universität Trier, D-54286 Trier, Germany, and GeoForschungsZentrum, \\ Telegrafenberg A26, D-14473 Potsdam, Germany
}

Received 7 August 1994; accepted 11 December 1994

Key words: Younger Dryas, pollen, diatoms, varves, laminated sediment, Laacher See Tephra, Holzmaar, rates of change, sequence splitting, variance partitioning, redundancy analysis

\begin{abstract}
A high-resolution pollen and diatom stratigraphy has been studied from late-glacial annually laminated sediments of Holzmaar ( $425 \mathrm{~m}$ a.s.1., Germany). The sediment sequence studied comprises 475 varves and includes two environmental perturbations of different type and duration: the short, abrupt deposition of the late Allerød tephra layer of the Laacher See volcano (LST, $11000 \mathrm{yr}$ B.P.), and the more gradual onset of the 'Younger Dryas climatic cooling.

Numerical analyses involving (partial) redundancy analyses in connection with Monte Carlo permutation tests suggest that the deposition of $78 \mathrm{~mm}$ of Laacher See Tephra had a statistically significant effect on the pollen stratigraphy (percentage and accumulation rates), most probably because of the proximity of the site to the volcano. The diatom accumulation rates also show a statistically significant change, whereas the diatom percentage data do not change significantly. The between-sample rates-of-change in both biostratigraphies are higher at and just after the LST event than at the transition to the Younger Dryas biozone. Sequence splitting of pollen and diatom accumulation rate data also shows a clustering of significant splits at the LST event. A close correlation between changes in the pollen and diatom percentage data for the investigated time-interval suggests a common underlying climatic signal, whereas the accumulation rates of both biostratigraphies behave more individualistically and show more short-term variability due, in part, to the inherent noise in the two data sets. Variance partitioning shows that the local pollen and diatom assemblage zones explain much of the variance in the data-sets. Statistical modelling using redundancy analysis shows that the changes in the diatom assemblages are best predicted by the Younger Dryas biozone and the main changes in the pollen stratigraphy (as represented by the first PCA axis of the pollen data).

The results suggest that the biostratigraphies studied at Holzmaar reflect generally stable systems which were disturbed by the deposition of the Laacher See Tephra. After a phase of recovery both systems again reached a new phase of stability prior to the long-term Younger Dryas climatic deterioration that perturbed the assemblages again. The very close and statistically significant parallelism between the major stratigraphical patterns in the pollen and diatom percentage data highlights the responses of the two biological systems to environmental perturbations at different temporal scales.
\end{abstract}

\section{Introduction}

Lake sediments contain remains of a number of biotic and abiotic variables that can provide a basis for recon- structing past environmental conditions. Many of these potential indicators originate not only from the aquatic environment but also from the catchment of the lake. It is therefore possible to trace past changes in terrestrial 


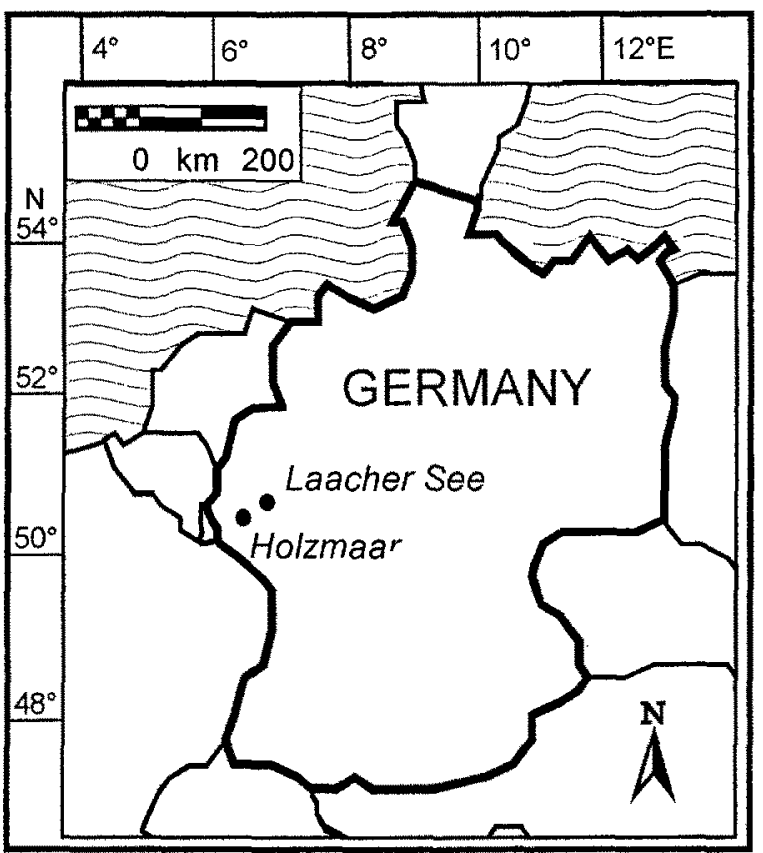

Fig. I. Map of Germany showing the location of Holzmaar and Laacher See.

and aquatic ecosystems on a time-scale that commonly exceeds the duration of long-term monitoring studies (Jacobson, 1988; Charles et al., 1994). Moreover, it is sometimes even possible to look at the behaviour of past ecosystems at a micro-scale (cf. Delcourt et al., 1982; Birks, 1986), depending on the available temporal and spatial resolution of the fossil record. The spatial resolution is largely a function of the surface area of the lake (Jacobson \& Bradshaw, 1981; Prentice, 1985, 1988). The highest possible time-resolution in lacustrine deposits is achieved by using annually laminated sediments or varves, where each year is represented by two or several discrete layers (O'Sullivan, 1983; Saarnisto, 1986; Peglar, 1993).

The speed of reaction of aquatic and terrestrial ecosystems to perturbations such as forest fire or rapid climatic change is commonly thought to be different. Aquatic vegetation may react much faster than terrestrial vegetation for several reasons. In relation to climatic improvement, Iversen $(1954,1964)$ discusses the advantages of studying aquatic plants. Most aquatic plants have a short life-cycle, i.e. they are annuals and after germination they produce propagules each year. These propagules are efficiently dispersed over long distances by, for example, aquatic birds. Furthermore the ability to colonize a lake by water plants may be independent of pedogenesis. These features are also

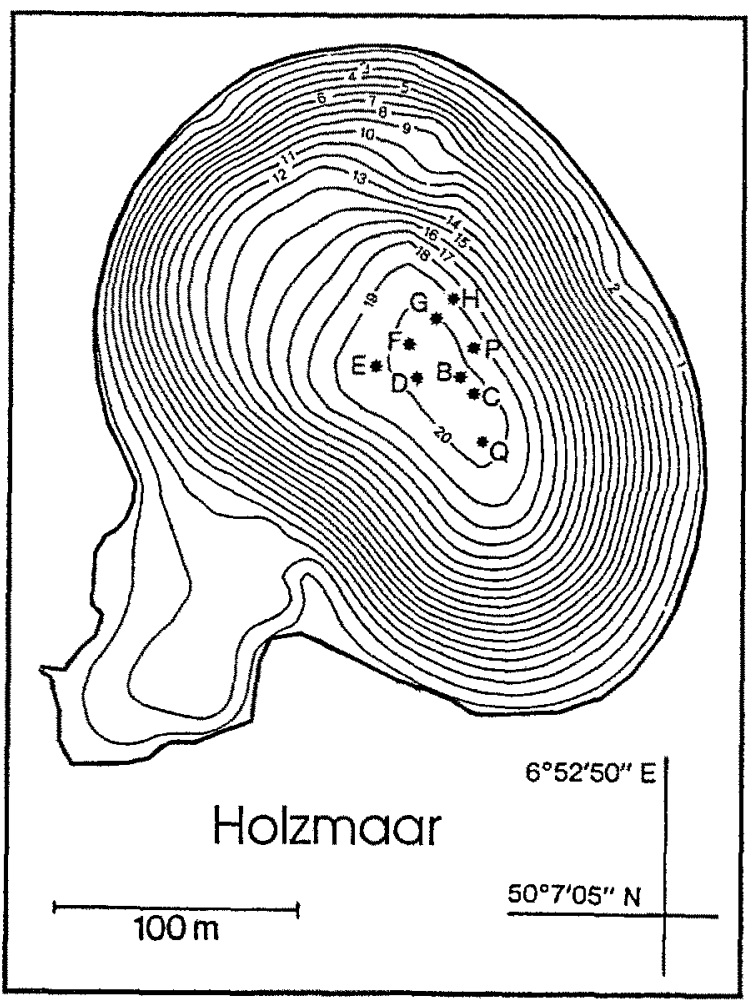

Fig. 2. Bathymetric map of Holzmaar with coring sites. Contours are in metres.

true for algae which have an even shorter generation time. Therefore, aquatic plants and algae may react with a minor or even without any time-lag to rapid environmental change, in contrast to terrestrial vegetation where factors such as migration and pedogenesis are assumed to play an important role (Wright, 1984; Birks, 1986; Pennington, 1986; Ammann, 1989).

In the present study we examine the response of presumed stable aquatic and terrestrial systems to two different and distinct types of environmental perturbations on the basis of a high-resolution time-scale provided by annually laminated sediments. The disturbances are:

(i) the eruption of the nearby Laacher See volcano as a single event of an extremely short duration (weeks to months, see Van den Bogaard \& Schmincke, 1985);

(ii) the climatic cooling evidenced in many European biostratigraphies at the transition from the Allerød to the Younger Dryas biozone (e.g. Coope, 1977; Sissons, 1979; Welten, 1982). This transition is also well documented in the oxygen isotope record of the Greenland ice sheet (see, e.g., Dansgaard et al., 1982) as well as in autigenic freshwater carbonates (e.g. Eicher 


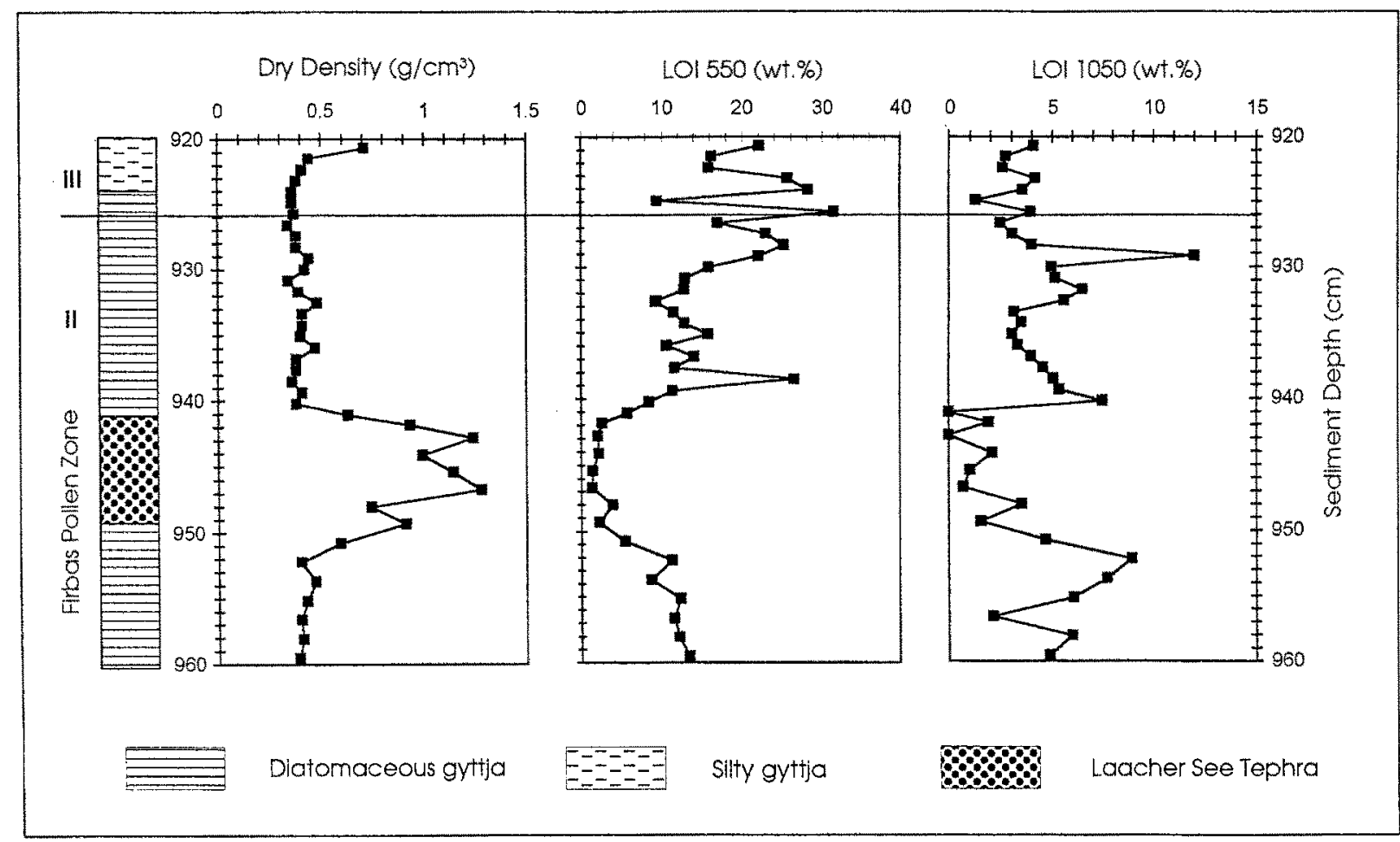

Fig. 3. Lithology, dry density and estimates of organic matter (LOI 550) and of carbonates (LOI 1050) for the Holzmaar sedimentary sequence examined. The horizontal line marks the transition from the Allerød (II) to the Younger Dryas (II) biozone.

\& Siegenthaler, 1976; Lotter et al., 1992a) and may have occurred within 50-100 years (Roszanski et al., 1992; Alley et al., 1993).

These two perturbations of different type and duration provide an opportunity to study past ecological dynamics in response to rapid environmental change. Our main interest is focused on the reaction of aquatic and terrestrial biota to these two very different types of environmental change.

\section{The site}

Holzmaar, the site we have investigated, is located in the West Eifel Volcanic Field of the Rhenish Massif, $50 \mathrm{~km}$ northeast of Trier, Germany $\left(6^{\circ} 53^{\prime} \mathrm{E}, 50^{\circ} 7^{\prime} \mathrm{N}\right)$ at an elevation of $425 \mathrm{~m}$ a.s.l. (Fig. 1). The Holzmaar basin has a circular morphology and is of volcanic origin. The lake was formed c. 40000-70000 years ago (Büchel, 1984) and has a modern maximum water depth of $20 \mathrm{~m}$ (Fig. 2), a surface area of $0.58 \times 10^{5} \mathrm{~m}^{2}$, and a volume of $0.64 \times 10^{6} \mathrm{~m}^{3}$. The shallow arm in the southwestern corner of the lake basin was created by a dam built during the $16^{\text {th }}$ or $17^{\text {th }}$ century, which caused a rise in lake level of about $3 \mathrm{~m}$. Holzmaar is a mesotrophic to eutrophic and dimictic lake with a slight trend towards anoxic conditions below a water depth of $15 \mathrm{~m}$. Hustedt (1954) described the diatom flora in surficial sediments and listed Cyclotella comta, C. stelligera, Stephanodiscus astraea var. minutula, and Synedra acus var. angustissima as the dominant planktonic taxa.

The bedrock of the catchment $\left(2.06 \mathrm{~km}^{2}\right.$ area $)$ is composed of Devonian sand- and silt-stones, thinly covered with pyroclastics and loess-like deposits. Most of the drainage basin is used as arable land today. The natural vegetation of beech forests is restricted to the rim of the crater walls. Modern climatic conditions are characterized by a mean annual precipitation of $800 \mathrm{~mm}$ and a mean annual temperature of $7.5^{\circ} \mathrm{C}$, with mean July temperatures of $16^{\circ} \mathrm{C}$ and mean January temperatures of $-1{ }^{\circ} \mathrm{C}$.

\section{Methods}

Several sediment cores were recovered from the centre of Holzmaar (see Fig. 2) with a modified Living- 


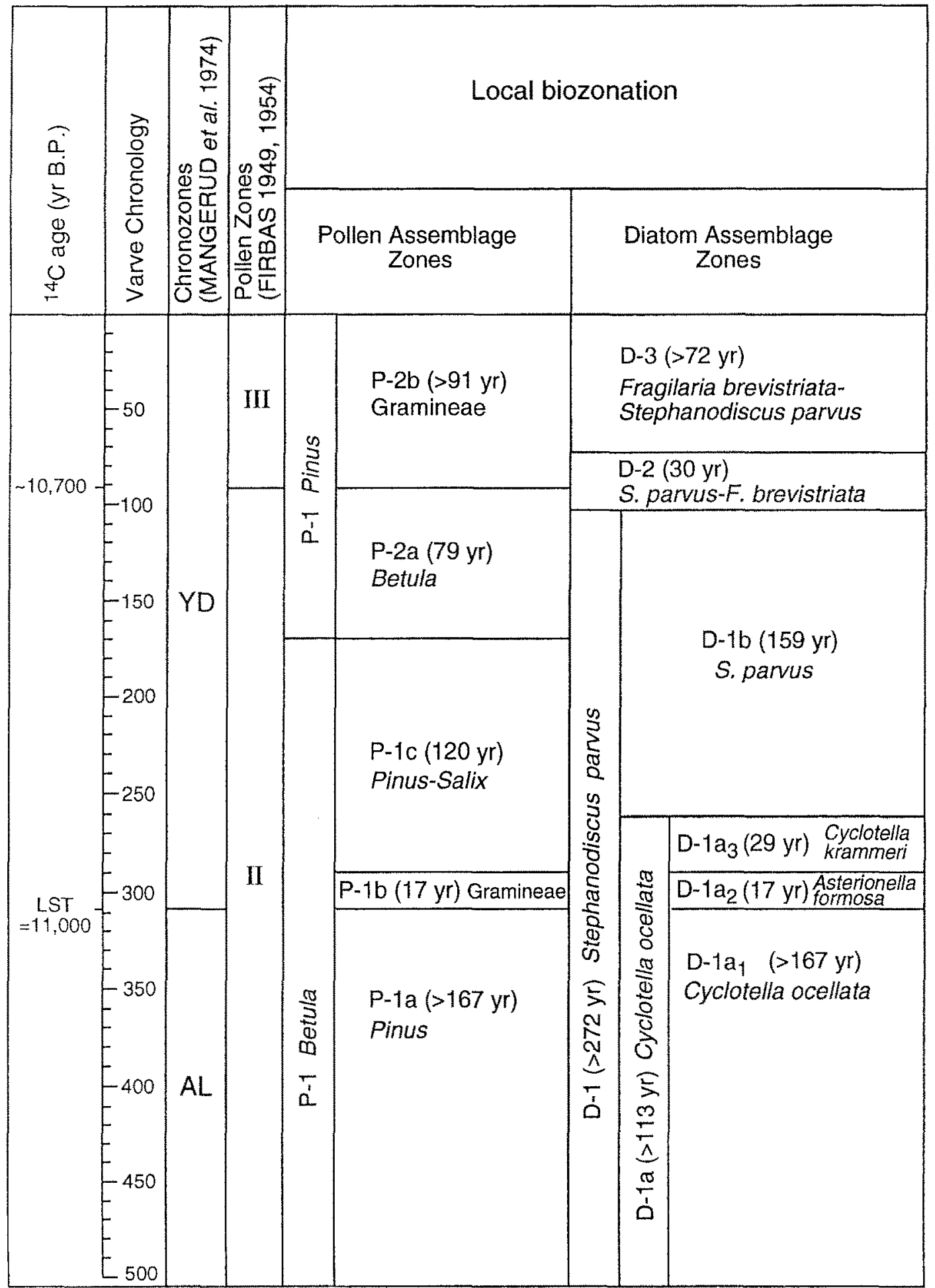

Fig. 4. Local pollen and diatom assemblage zones and their duration in relation to chronozones and Firbas biozones. 
stone piston corer. Microstratigraphical investigations of large-sized sediment thin sections from overlapping cores $\mathrm{HZM}-\mathrm{B} / \mathrm{C}$ were carried out with a petrographic microscope. Varves were counted as the mean number of varves for every $10 \mathrm{~mm}$. Dry density (drying at $105^{\circ} \mathrm{C}$ ), organic carbon (loss-on-ignition at $550{ }^{\circ} \mathrm{C}=$ LOI 550), and inorganic carbon (loss-onignition at $1050^{\circ} \mathrm{C}=\mathrm{LOI} 1050$ ) were estimated on samples from core series HZM-E/F (see Fig. 3), with a stratigraphical resolution of $1 \mathrm{~cm}$ increments above the Laacher See Tephra (LST) and $2 \mathrm{~cm}$ below LST.

Forty contiguous sediment samples of Holzmaar core HZM-B/C, comprising a known volume and number of varves (cf. Table 1), were sampled for pollen and diatoms. Pollen samples were prepared according to Lotter (1988) and spiked with Lycopodium tablets for estimation of absolute pollen concentrations. The pollen sum includes at least 350 arboreal pollen (AP) and non-arboreal pollen (NAP) per sample. Spores and pollen of obligate aquatics are excluded from this sum. Diatom samples were prepared with $30 \% \mathrm{H}_{2} \mathrm{O}_{2}$ and $10 \% \mathrm{HCl}$ according to Battarbee (1986) and spiked with microspheres (Battarbee \& Kneen, 1982). A minimum of 400 valves were counted per sample. Taxonomic identification of diatoms follows Krammer \& Lange-Bertalot (1986-1991). Accumulation rates and their statistical errors were estimated according to Maher (1981).

Zonation of both the pollen and diatom stratigraphy (expressed as percentages) was carried out numerically using the methods described by Birks \& Gordon (1985) and Grimm (1987). Chord distance was used as the dissimilarity coefficient. Taxa with less than three occurrences and with relative abundance of less than $0.5 \%$ were excluded for the numerical zonation, leaving a total of 26 pollen taxa and 36 diatom taxa. The zonation adapted was based on consistency between the results from different numerical procedures (Birks \& Gordon, 1985).

The pollen and diatom data were analyzed numerically using various procedures, as discussed below. As a preliminary guide to the choice of numerical methods that assume either a linear or a unimodal response of taxa to underlying gradients (Ter Braak \& Prentice, 1988), detrended canonical correspondence analyses (Ter Braak, 1986, 1987) were done. In these analyses sample age was the only constraining external variable, detrending was by segments, and non-linear rescaling was applied, resulting in the first axis being scaled in standard deviation (SD) units (Hill \& Gauch, 1980). These are a simple measure of the compo- sitional turnover within the interval $920-960 \mathrm{~cm}$ at Holzmaar shown by the pollen and diatom data when expressed as relative percentages and as annual accumulation rates. The results (Table 2) show that all the data-sets have short gradient lengths $(<1$ SD unit) and that there is greater total variance (=inertia) in the diatom data than in the pollen data. Interestingly there is little difference in total variance between the percentage and accumulation-rate data. In light of the short gradient lengths, linear-based numerical methods such as principal components analysis and redundancy analysis (Ter Braak \& Prentice, 1988) have been used throughout this study.

\section{Results}

\section{Sediment stratigraphy}

This study focuses on the late Allerød and early Younger Dryas sediment including the Laacher See Tephra layer (LST). This part of the sediment sequence from Holzmaar (depth range from $920-960 \mathrm{~cm}$ ) is composed of four major lithological units (see Table 3 and Fig. 3). Sediment composition as well as dry density profiles are illustrated in Fig. 3. The diatomaceous gyttja is characterized by low dry densities with mean values of $0.4 \mathrm{~g} \mathrm{~cm}^{-3}$ and high values for organic matter (10-30\% LOI 550) and carbonate (4-12\% LOI 1050). The minerogenic layer of LST has high dry densities $\left(>1 \mathrm{~g} \mathrm{~cm}^{-3}\right)$ and very low loss-on-ignition values. The lithological transition from Allerød-age diatomaceous gyttja to the silty gyttja of the Younger Dryas at $924 \mathrm{~cm}$ is characterized by an increase in dry density related to the higher minerogenic composition. The organic matter (LOI 550) record shows much variation at this transition, probably caused by various dynamic and highly variable erosional processes in the catchment and around the lakeshore. Carbonate values drop below 4\% LOI 1050. These sediments are annually laminated (organic varves) and provide a reliable tool for dating purposes. The varves consist of spring/summer layers with chrysophyte cysts, planktonic diatoms and calcium carbonate or sometimes siderite crystals, and autumn/winter layers with benthic diatoms and minerogenic detritus (Zolitschka, 1990). For this study the varve record was used to establish a relative chronology for the time window from the late Allerod biozone to the early Younger Dryas biozone (Table 1 and Fig. 4). 


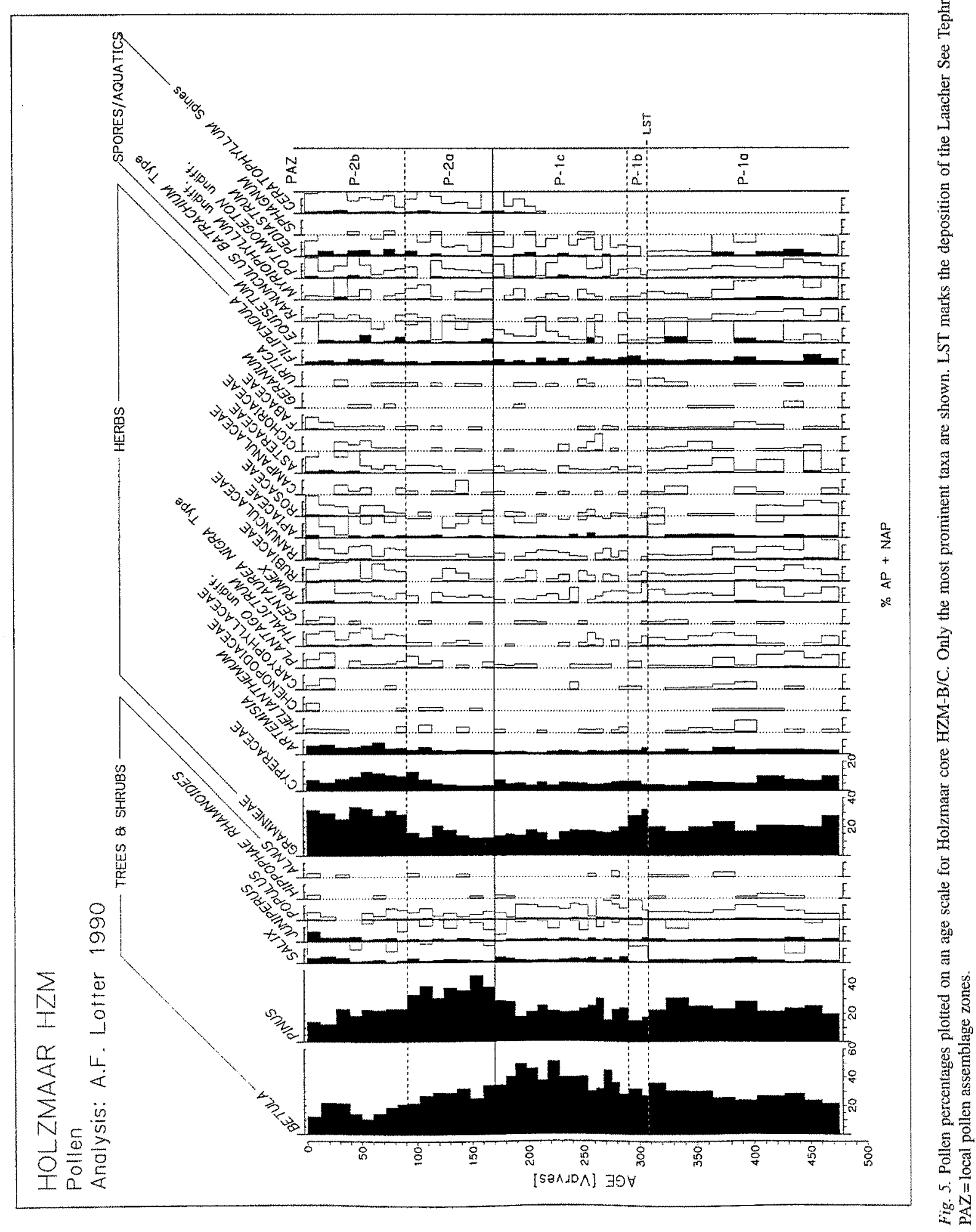




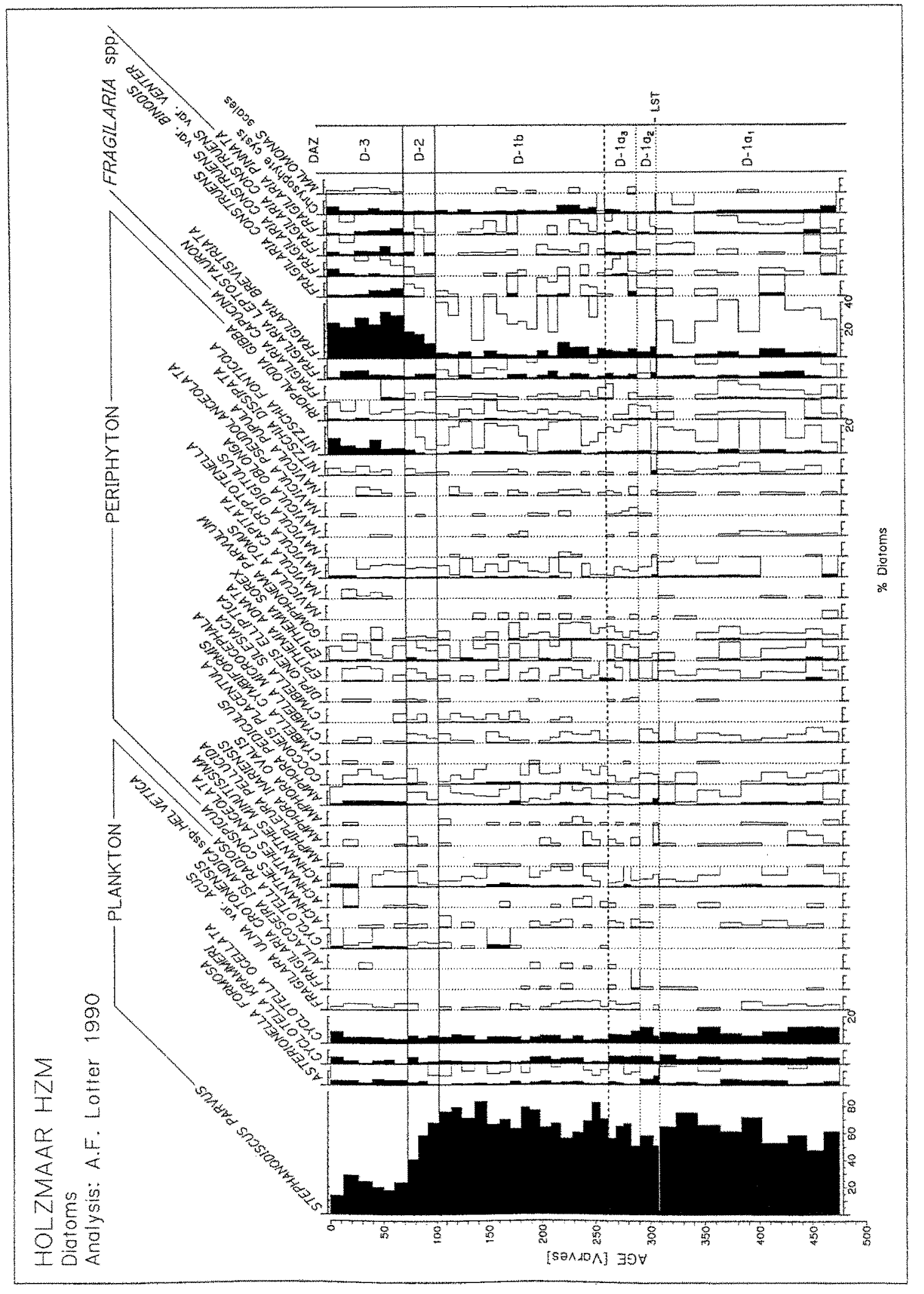


Table 1. Varve chronology of the Holzmaar sediments investigated in this study

\begin{tabular}{|c|c|c|c|c|c|c|}
\hline Sample \# & \#varves & Time-scale (varves) & Depth $(\mathrm{cm})$ & Volume $\left(\mathrm{cm}^{3}\right)$ & $\mathrm{mm} \mathrm{yr}^{-1}$ & $\mathrm{yr} \mathrm{cm}-1$ \\
\hline 1 & 12 & 0 & 919.8 & 0.45 & 0.417 & 24.00 \\
\hline 2 & 14 & 12 & 920.3 & 0.81 & 0.643 & 12.60 \\
\hline 3 & 13 & 26 & 921.2 & 1.08 & 0.923 & 10.83 \\
\hline 4 & 11 & 39 & 922.4 & 0.99 & 1.000 & 10,00 \\
\hline 5 & 10 & 50 & 923.5 & 0.54 & 0.600 & 16.67 \\
\hline 6 & 12 & 60 & 924.1 & 0.81 & 0.750 & 13.33 \\
\hline 7 & 10 & 72 & 925.0 & 0.45 & 0.500 & 20.00 \\
\hline 8 & 9 & 82 & 925.5 & 0.45 & 0.555 & 18.00 \\
\hline 9 & 11 & 91 & 926.0 & 0.45 & 0.455 & 22.00 \\
\hline 10 & 12 & 102 & 926.5 & 0.72 & 0.667 & 15.00 \\
\hline 11 & 10 & 114 & 927.3 & 0.54 & 0.600 & 16.67 \\
\hline 12 & 12 & 124 & 927.9 & 0.90 & 0.833 & 12.00 \\
\hline 13 & 12 & 136 & 928.9 & 0.54 & 0.500 & 20.00 \\
\hline 14 & 12 & 148 & 929.5 & 0.54 & 0.500 & 20.00 \\
\hline 15 & 10 & 160 & 930.1 & 0.45 & 0.500 & 20.00 \\
\hline 16 & 10 & 170 & 930,6 & 0.81 & 0.900 & 11.11 \\
\hline 17 & 8 & 180 & 931.5 & 0.90 & 1.250 & 8.00 \\
\hline 18 & 10 & 188 & 932.5 & 0.45 & 0.500 & 20.00 \\
\hline 19 & 10 & 198 & 933.0 & 0.45 & 0.500 & 20.00 \\
\hline 20 & 9 & 208 & 933.5 & 1.17 & 1.444 & 6.92 \\
\hline 21 & 11 & 217 & 934.8 & 0.45 & 0.455 & 22.00 \\
\hline 22 & 10 & 228 & 935.3 & 0.45 & 0.500 & 20.00 \\
\hline 23 & 8 & 238 & 935.8 & 0.45 & 0.625 & 16.00 \\
\hline 24 & 8 & 246 & 936.3 & 0.45 & 0.625 & 16.00 \\
\hline 25 & 7 & 254 & 936.8 & 0.45 & 0.714 & 14.00 \\
\hline 26 & 7 & 261 & 937.3 & 0.45 & 0.714 & 14.00 \\
\hline 27 & 7 & 268 & 937.8 & 0.45 & 0.714 & 14.00 \\
\hline 28 & 7 & 275 & 938.3 & 0.45 & 0.714 & 14.00 \\
\hline 29 & 8 & 282 & 938.8 & 0.90 & 1.250 & 8.00 \\
\hline 30 & 12 & 290 & 939.8 & 0.63 & 0.583 & 17.14 \\
\hline 31 & 5 & 302 & 940.5 & 0.90 & 2.000 & 5.00 \\
\hline LST & 1 & 307 & 941.5 & & 78.000 & 0.13 \\
\hline 32 & 15 & 308 & 949.3 & 0.72 & 0.533 & 18.75 \\
\hline 33 & 20 & 323 & 950.1 & 0.90 & 0.500 & 20.00 \\
\hline 34 & 21 & 343 & 951.1 & 0.90 & 0.476 & 21.00 \\
\hline 35 & 19 & 364 & 952.1 & 0.90 & 0.526 & 19.00 \\
\hline 36 & 19 & 383 & 953.1 & 0.90 & 0.526 & 19.00 \\
\hline 37 & 24 & 402 & 954.1 & 1.35 & 0.625 & 16.00 \\
\hline 38 & 18 & 426 & 955.6 & 0.90 & 0.556 & 18.00 \\
\hline 39 & 16 & 444 & 956.6 & 0.90 & 0.625 & 16.00 \\
\hline \multirow[t]{2}{*}{40} & 15 & 460 & 957.6 & 0.63 & 0.467 & 21.43 \\
\hline & & 475 & 958.3 & & & \\
\hline
\end{tabular}

\section{Chronology}

On the basis of replicate varve counts, a floating absolute chronology was established (Table 1). The top of the first sample was arbitrarily given the year 0 . The LST represents an excellent isochronous time-marker for correlations. It was deposited between varve 307 and 308 (Table 1). Several radiocarbon dates through- 
Table 2. Results of detrended canonical correspondence analyses (detrending by segments and non-linear rescaling) with sample age as the sole constraining external variable

\begin{tabular}{lllllll}
\hline & \multicolumn{2}{c}{$\begin{array}{l}\text { Diatom data } \\
\text { Percentage }\end{array}$} & Accumulation rate & & $\begin{array}{l}\text { Pollen data } \\
\text { Percentage }\end{array}$ & Accumulation rate \\
\cline { 2 - 3 } \cline { 5 - 6 } Number of taxa & 29 & 29 & 18 & 18 \\
Gradient length (SD units) & 0.84 & 0.70 & 0.30 & 0.44 \\
Total inertia & 0.38 & 0.36 & 0.14 & 0.13 \\
\hline
\end{tabular}

Table 3. Sediment lithology of Holzmaar core HZM-B/C according to Troels-Smith (1955)

\begin{tabular}{ll}
$896-924 \mathrm{~cm}$ & Silty gyttja, laminated (Ag2, As1, Sh1, Lso+) \\
$924-941 \mathrm{~cm}$ & Carbonaceous and slightly silty diatomaceous gyttja, laminated (Sh2, Lsol, Ag1, Lc+) \\
$941-949 \mathrm{~cm}$ & Laacher See Tephra, grainy, homogenous (Gmin4) \\
$949-1024 \mathrm{~cm}$ & Carbonate-rich diatomaceous gyttja, laminated (Sh2, Lsol, Lcl) \\
\hline
\end{tabular}

out Central Europe indicate an age of $c .11000$ radiocarbon years B.P. for this prominent volcanic ash layer (e.g. Siraka, 1975; see also Ammann \& Lotter, 1989 and references therein). Therefore, this event can be used to mark the boundary between the chronozones of Allerød (AL) and Younger Dryas (YD, Fig. 4, see also Mangerud et al., 1974; Lotter et al., 1992b). In terms of absolute ages, Hajdas et al. (1993) have dated the LST to $12350 \pm 135 \mathrm{cal}$. years B.P. and the onset of the Younger Dryas biozone to $12125 \pm 86 \mathrm{cal}$. years B.P. in laminated Swiss lake sediments.

\section{Pollen stratigraphy}

The high-resolution pollen stratigraphy (Fig. 5) compares well with a previously published pollen stratigraphy from Holzmaar (Usinger \& Wolf in Zolitschka et al., 1992) as well as with other palynological investigations of Maar lakes in the Eifel region by Straka (1975) and Usinger (1982, 1984). The investigated pollen stratigraphy includes the last part of the Allerød biozone (II sensu Firbas, 1949, 1954) as well as the onset of the Younger Dryas biozone (III, see Fig. 4).

The numerical zonation revealed two major local pollen assemblage zones (PAZ), both of which can be further subdivided into sub-zones (see Fig. 4). During its lower part PAZ P.1 is characterized by high values of Betula and Pinus pollen (PAZ P-1a). By means of biometric measurements of the birch pollen, Usinger (1982) was able to show that at the nearby Meerfelder Maar (c. $7 \mathrm{~km}$ away) both Betula pubescens and B. pen- dula were present during the pine phase of the Allerød biozone (II). The Populus values in Meerfelder Maar are somewhat higher during this period which could be a local site effect, a result of the $100 \mathrm{~m}$ higher elevation, or a combination of both.

The LST interrupts the late Allerød pollen record abruptly for $78 \mathrm{~mm}$ (Fig. 3). Two samples directly above the LST are characterized by higher NAP values, especially by increased percentages of Gramineae pollen (Fig. 5). These two samples, therefore, form a separate sub-PAZ $(\mathrm{P}-1 \mathrm{~b})$. A similar phenomenon of increased Gramineae pollen just after the LST has been observed in Meerfelder Maar (Usinger, 1982, 1984) as well as at other central European sites (Birks \& Lotter, 1994).

Following this short interruption, Betula still dominates the pollen spectra with Pinus as a subdominant taxon. During this sub-PAZ $(\mathrm{P}-1 \mathrm{c})$ the vegetation may have consisted of open birch forests. In the absence of any macrofossil analysis and of any occurrences of Pinus stomata, it is difficult to know if pine was present locally during this part of the Allerød biozone (II) in the catchment of Holzmaar. However, with the increase in pine percentages at the onset of local PAZ P-2a stomata of Pinus do occur. This agrees well with results from other parts of Europe where pine macrofossils indicate the local presence of this tree when pine pollen percentages exceed 20-30\% (e.g. Ammann \& Tobolski, 1983; Tobolski, 1985; Schneider \& Tobolski, 1985; Lotter, 1988). 
Table 4. Results of (partial) redundancy analysis (RDA) of the impact of the Laacher See Tephra on the diatom and pollen assemblages at Holzmaar. The values are exact probability values based on 999 restricted Monte Carlo permutations. The accumulation-rate data were $\log _{e}(y+1)$ transformed prior to RDA. A variance-covariance matrix between variables was used for these data. The percentage data were $\log _{\epsilon}(y+1)$ transformed prior to RDA. Double centring was applied so as to implement log-linear contrast RDA (Ter Braak, 1986).

$\mathrm{AR}=$ accumulation rates; $\%=$ percentage data

\begin{tabular}{llllll}
\hline Model & Covariables & Diatom AR & Diatom \% & Pollen AR & Pollen $\%$ \\
\hline Allerød+Age+Ash & - & $0.01^{* *}$ & $0.01^{* *}$ & $0.01^{* *}$ & $0.01^{* *}$ \\
Ash & Allerød+Age & $0.01^{* *}$ & $0.14 \mathrm{~ns}$ & $0.01^{* *}$ & $0.04^{*}$ \\
\hline
\end{tabular}

*** significant at $p \leq 0.01$

* significant at $0.01<p \leq 0.05$

ns not significant at $p>0.05$

Table 5. Results of principal components analysis (variance-covariance matrix between variables) expressed as percentage variance represented by axes 1 and 2 . The ratio of the eigenvalues of axis 1 to axis 2 is also given

\begin{tabular}{llllll}
\hline & \multicolumn{2}{l}{$\begin{array}{l}\text { Diatom data } \\
\text { Percentage }\end{array}$} & Accumulation rate & & \multicolumn{2}{l}{$\begin{array}{l}\text { Pollen data } \\
\text { Percentage }\end{array}$} & Accumulation rate \\
\cline { 2 - 3 } \cline { 5 - 6 } Axis $1 \%$ & 52.4 & 31.8 & 47.1 & 36.7 \\
Axis $2 \%$ & 8.2 & 16.0 & & 17.3 & 16.9 \\
Axis1/Axis2 & 6.39 & 1.99 & & 2.72 & 2.17 \\
\hline
\end{tabular}

The increasing NAP values, mainly Gramineae, characterize the onset of local PAZ P-2b (Fig. 5). The occurrence of $P$ inus stomata suggests that pine was still growing in the catchment of Holzmaar. The pine-birch woodland might have been more open or flowered less well than during PAZ P-1, as indicated by the increased percentage values of NAP. Considering the results from other Maar lakes (Straka, 1961, 1975; Usinger, 1982, 1984) and other palynologically investigated sites in Central Europe, this sub PAZ (P-2b) can be correlated with the Younger Dryas biozone (III).

\section{Diatom stratigraphy}

The diatom stratigraphy of the same sediment has been subdivided into three main diatom assemblage zones (DAZ, see Figs 4 and 6) The major part of the sequence is dominated by Stephanodiscus parvus (DAZ D-1). This whole DAZ is characterized by high amounts of planktonic diatoms (Fig. 7). On the basis of the abundance of Cyclotella ocellata, DAZ D-1 can be subdivided into an initial C. ocellata-rich sub-DAZ (D-1a), followed by sub-DAZ D-1b characterized by very high values of $S$. parvus. After the deposition of the LST the diatom stratigraphy can be further subdivided into an initial Asterionella formosa-rich (D-1 $\mathrm{a}_{2}$ ) phase and a second, Cyclotella krammeri-rich phase (D-1a $)$.

DAZD-2 represents a transition zone characterized by decreasing amounts of planktonic diatoms (mainly $S$. parvus) and increasing percentages of Fragilaria brevistriata, whereas DAZ D-3 is characterized by high amounts of periphyton, especially Fragilaria spp. (mainly F. brevistriata, see Fig. 7).

\section{Accumulation rates}

With the high temporal resolution available for this core (Table 1), it is possible to estimate accumulation rates (AR) for both pollen (Fig. 8) and diatoms (Fig. 9). These AR are thought to reflect, in part, the past abundances of terrestrial vegetation and of past diatom assemblages. Due to the short generation times of diatoms, their AR are generally more variable than the pollen AR (Fig. 10).

\section{Discussion}

The discussion centres on assessing the effects of the deposition of the LST and of the Younger Dryas cli- 


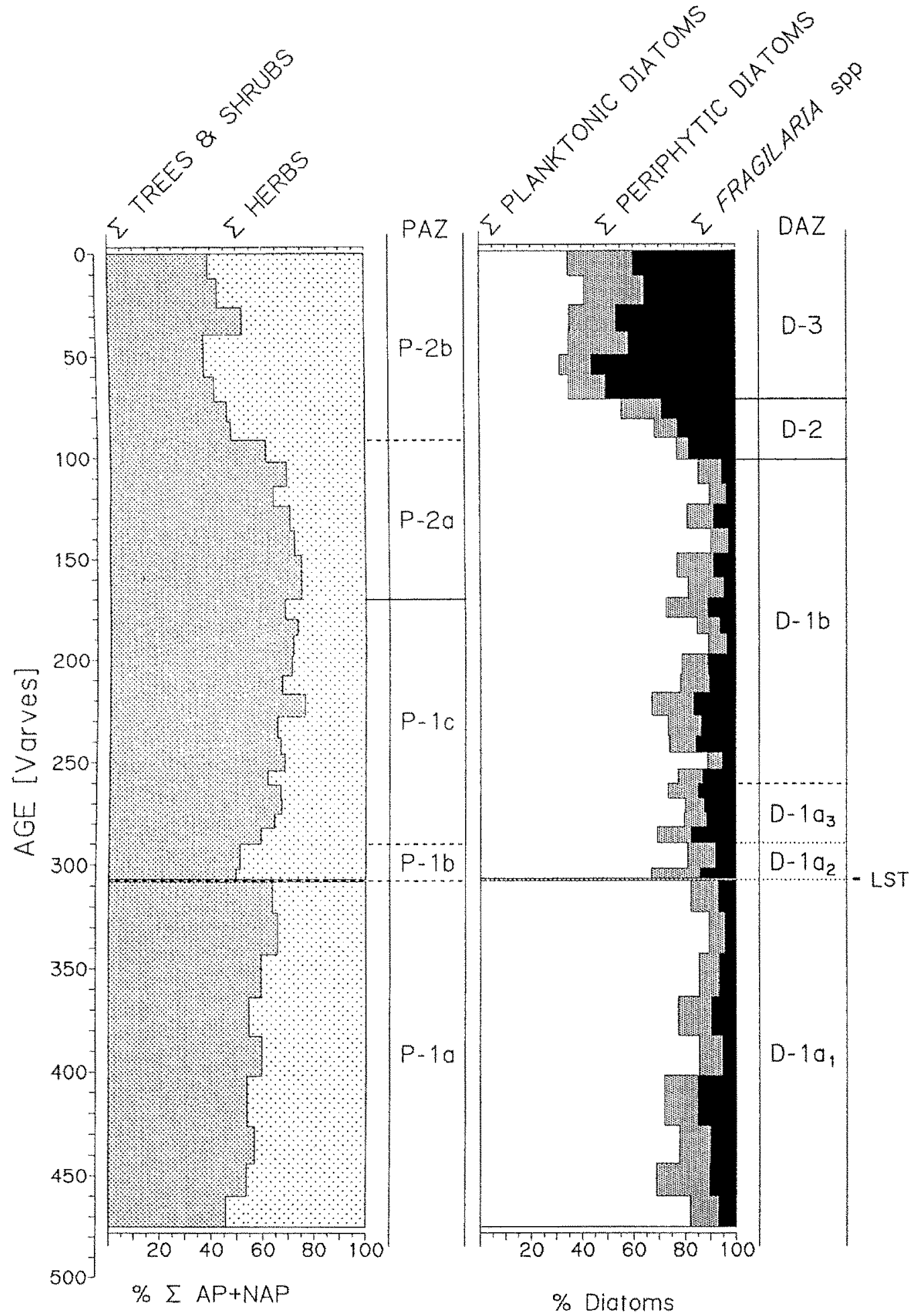

Fig. 7. Summary percentage diagram for pollen physiognomic life-forms and diatom life-forms of core Holzmaar HZM-B/C. LST marks the deposition of the Laacher See Tephra. PAZ = local pollen assemblage zones. DAZ= diatom assemblage zones. 
Table 6. Results of variance partitioning of the diatom and pollen percentage $(\%)$ and accurnulation rate (AR) data at Holzmaar using redundancy analysis and different sets of external 'predictor' variables. The statistical significance $(p)$ of each model was assessed by 99 restricted Monte Carlo permutations

\begin{tabular}{|c|c|c|c|c|c|}
\hline \multirow[t]{2}{*}{ Predictor } & & \multicolumn{2}{|c|}{ Diatoms } & \multicolumn{2}{|l|}{ Pollen } \\
\hline & & $\%$ & $\mathrm{AR}$ & $\%$ & AR \\
\hline \multirow[t]{2}{*}{ All } & $\%$ & 47.4 & 18.5 & 40.6 & 29.9 \\
\hline & $p$ & 0.01 & 0.01 & 0.01 & 0.01 \\
\hline \multirow[t]{2}{*}{ Sample age } & $\%$ & 20.1 & 8.7 & 5.9 & 2.8 \\
\hline & $p$ & $0.13 \mathrm{~ns}$ & $0.15 \mathrm{~ns}$ & $0.82 \mathrm{~ns}$ & $0.94 \mathrm{~ns}$ \\
\hline Younger Dryas/ & $\%$ & 41.1 & 12.8 & 30.4 & 10.0 \\
\hline Allerød biozones & $p$ & 0.01 & 0.01 & 0.01 & $0.37 \mathrm{~ns}$ \\
\hline Laacher See & $\%$ & 2.5 & 5.8 & 8.6 & 16.9 \\
\hline Tephra & $p$ & $0.89 \mathrm{~ns}$ & $0.32 \mathrm{~ns}$ & $0.52 \mathrm{~ns}$ & 0.01 \\
\hline \multirow[t]{2}{*}{ Local zones } & $\%$ & 46.1 & 18.4 & 39.4 & 29.0 \\
\hline & $p$ & 0.01 & 0.01 & 0.01 & 0.01 \\
\hline
\end{tabular}

ns $=$ not significant, $p>0.05$

matic deterioration on the diatom and pollen assemblages. After considering the effects of these perturbations, the discussion considers patterns of stratigraphical variation in the diatom and pollen data, rates of change, sequence splitting, and variance partitioning in the different data-sets, and statistical modelling of the observed changes in diatom stratigraphy in relation to a range of possible explanatory environmental variables.

\section{Laacher see tephra}

The eruption of the Laacher See volcano produced at least $5-10 \mathrm{~km}^{3}$ of phonolite magma (Van den Bogaard \& Schmincke, 1985; in comparison the Mt. St. Helens eruption in 1980 produced $c .1 \mathrm{~km}^{3}$, Findley, 1981) that spread over wide parts of Central and Northern Europe. Despite Holzmaar being located only $c .60 \mathrm{~km}$ to the southwest of the source of the tephra, its sedimentary record received only $78 \mathrm{~mm}$ of tephra and the amount of tephra deposited in its catchment may have been of the same magnitude. This was due mainly to the prevailing northwestern and southern winds during the time of the eruption of the Laacher See volcano that spread the major part of the eruptive tephra in these directions.

The tephra deposits may have affected the vegetation in the catchment as well as in the lake through burying or mechanical overloading of plants, depending on the thickness of the tephra cover. However, observations on the impact of the Mt. St. Helens eruption on terrestrial vegetation (Mack, 1981) show that, outside the actual blast zone where there was total destruction, the direct effects of ashfall were not severe.

The impact of the Laacher See Tephra on the diatom and terrestrial pollen assemblages at Holzmaar was assessed statistically using (partial) redundancy analysis and restricted Monte Carlo permutation tests (see Lotter \& Birks, 1993 for details). The results are summarised in Table 4 . The model where broad-scale climatic change (represented by the dummy variables Allerød and Younger Dryas), long-term unidirectional change (represented by sample age), and ash impacts (represented by a decreasing exponential model) are all used as explanatory variables is statistically significant $(p \leq 0.01)$ for all four data-sets. However, when the effects of climatic change and long-term shifts are partialled out as covariables, a statistically significant impact $(p \leq 0.05)$ of the LST is suggested for the diatom $\mathrm{AR}$, pollen $\mathrm{AR}$, and pollen percentage data, but not for the diatom percentage data.

These numerical analyses suggest that the LST had a statistically significant effect on the terrestrial pollen assemblages in terms of both relative composition and absolute rates, and presumably also on the composition and density of the terrestrial vegetation within the catchment of Holzmaar. This is not surprising considering the proximity of the site to the Laacher See volcano. The sample just above the LST shows not only higher NAP percentages (Fig. 7) but also higher AR for all taxa (Figs 8 and 10). However, it is 


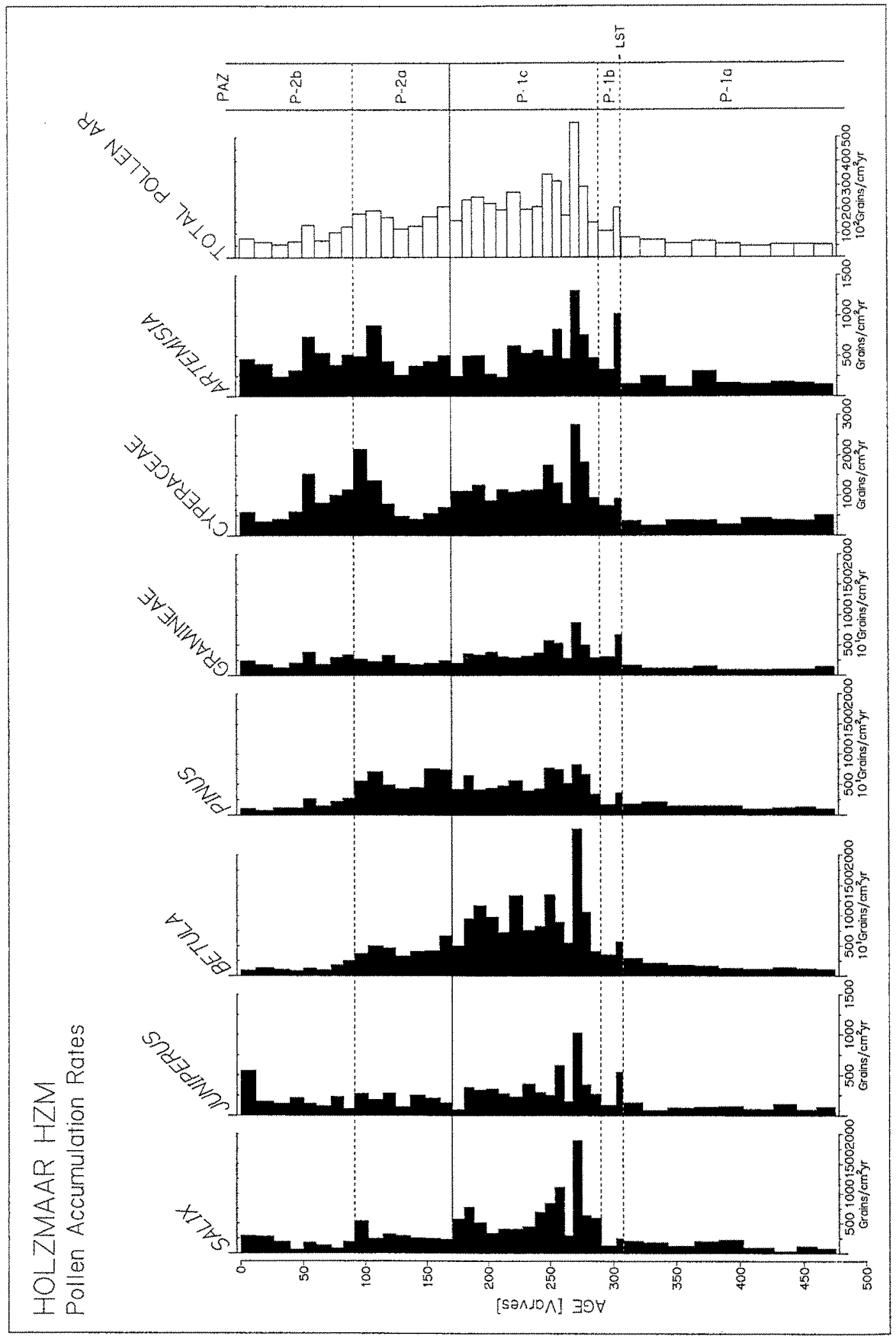

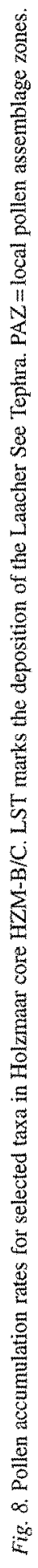




\section{HOLZMAAR HZM \\ Diatom Accumulation Rates}

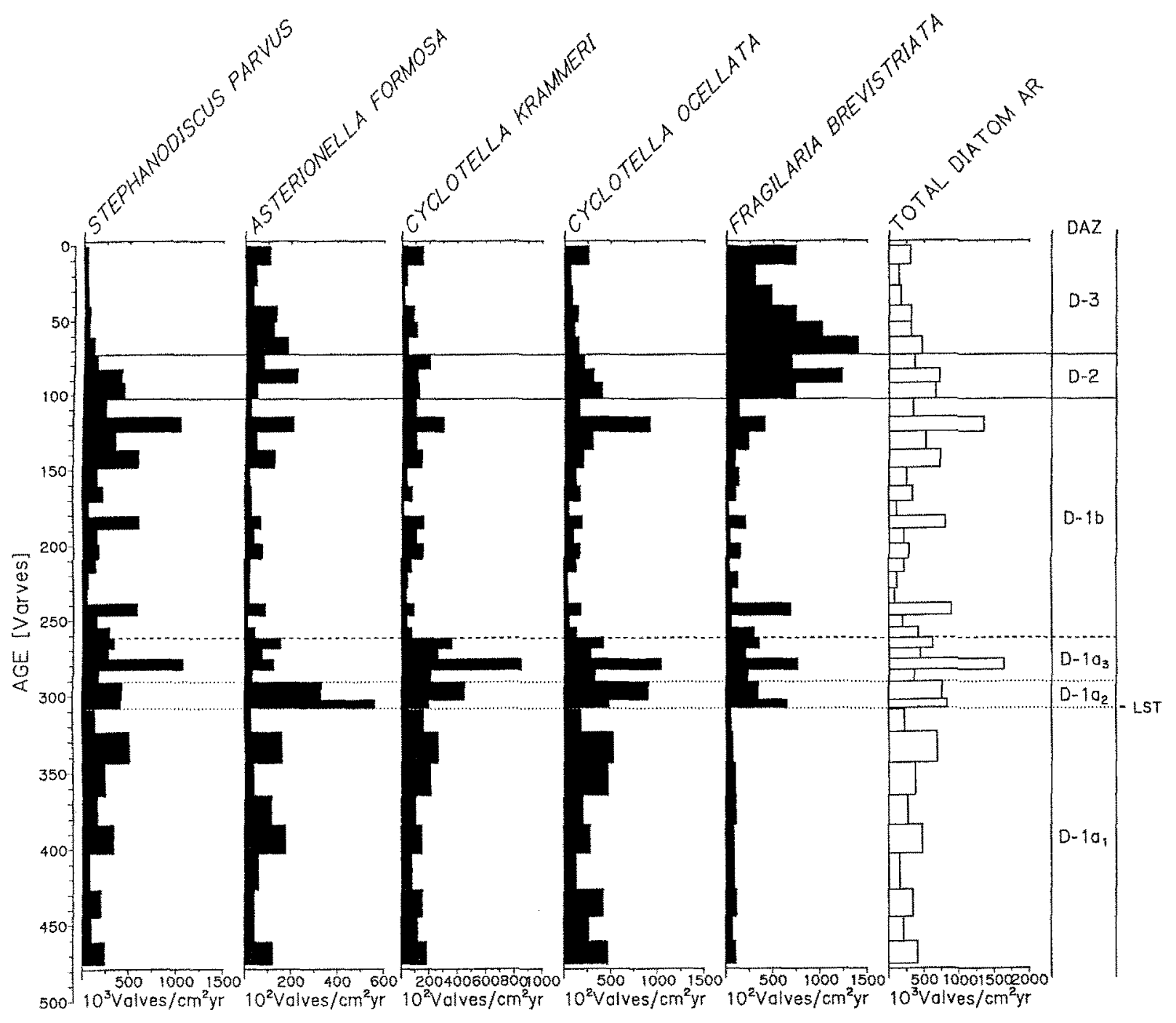

Fig. 9. Diatom accumulation rates for selected taxa in Holzmaar core HZM-B/C. LST marks the deposition of the Laacher See Tephra. $\mathrm{DAZ}=$ diatom assemblage zones.

mainly the pollen AR of light-demanding taxa such as Juniperus, Artemisia, and Gramineae that increase in the sample just above the LST. This sample contains 5 varves (Fig. 8). In contrast, only the diatom AR appear to have been impacted significantly by the LST. There is a non-significant $(p=0.14)$ result for a partial redundancy analysis of the percentage diatom data suggesting that no statistically significant change occurred in diatom composition in response to the LST deposition (Birks \& Lotter, 1994), but that the diatom AR show a statistically significant response to the LST. The LST effects on the Holzmaar diatom assemblages were thus on their absolute abundances rather than on their relative abundance and composition.

Limnological studies in Washington lakes receiving only airborne tephra after the Mt. St. Helens eruption showed no major effect on either water chemistry or biology, whereas the lakes in the blast zone 

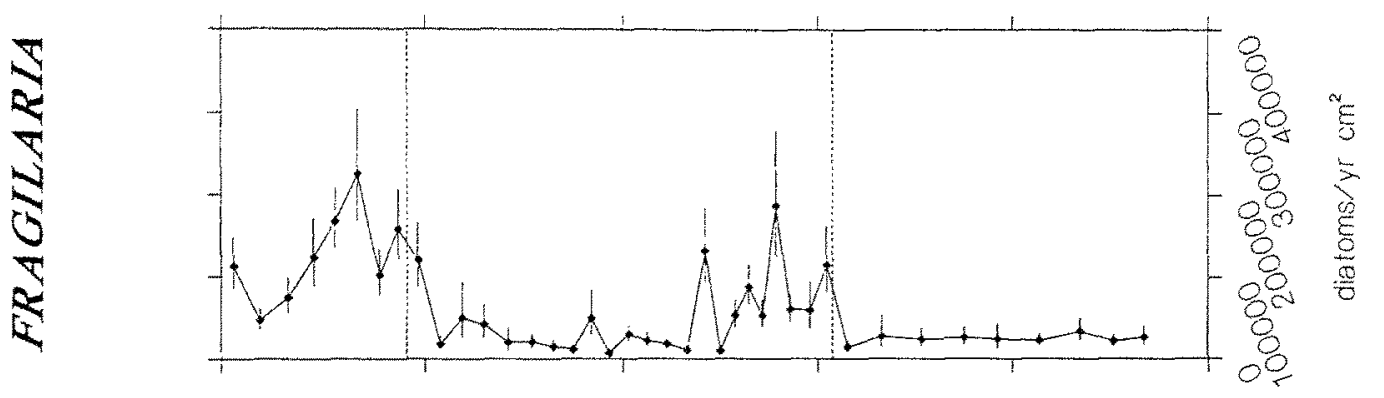

要

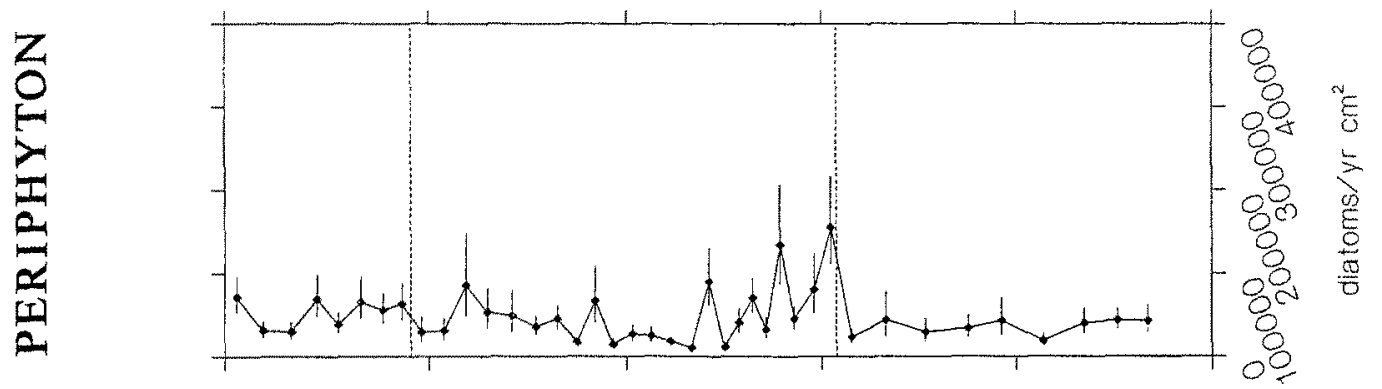

है

है

.

롱

点

氖导

焉

$z$
0
$z$
$z$
$z$
$z$

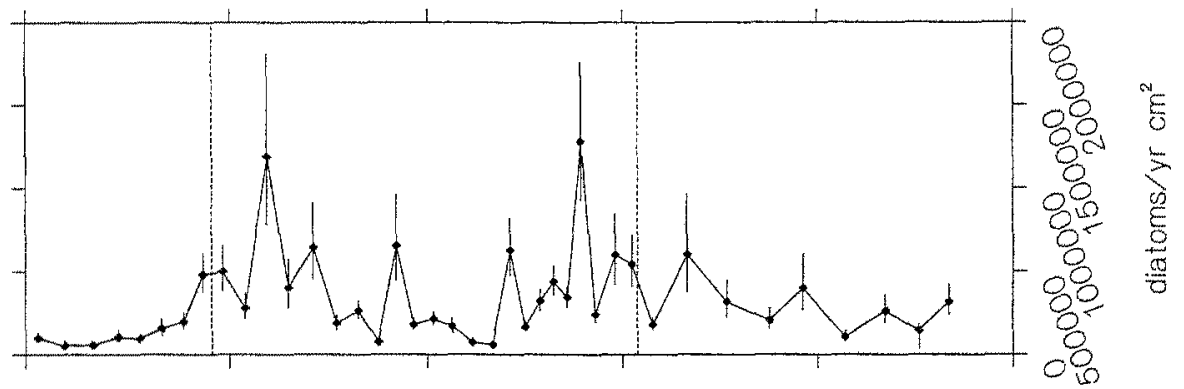

के

2

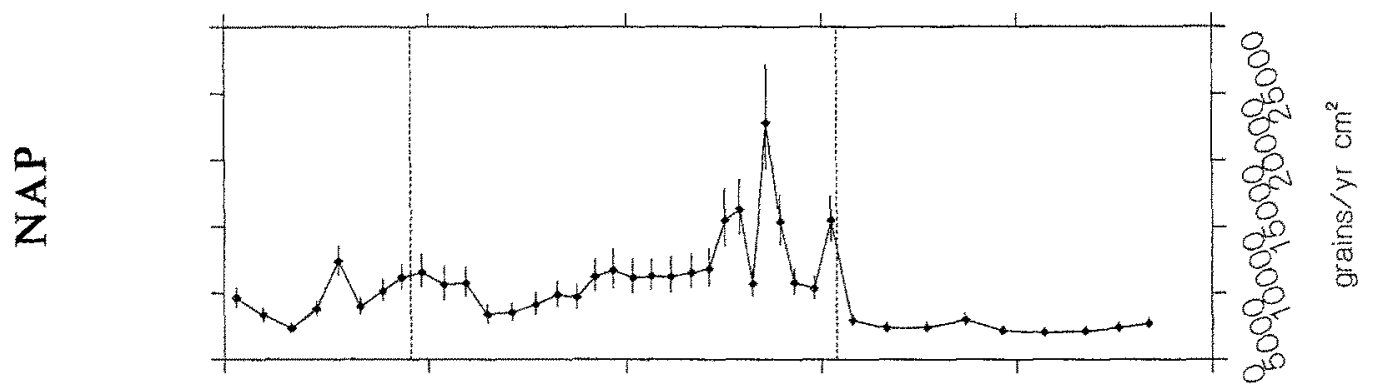

흘

要

焉

志

i

롱

\&

马्ّ.

원

蛋

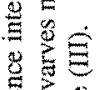

递豆

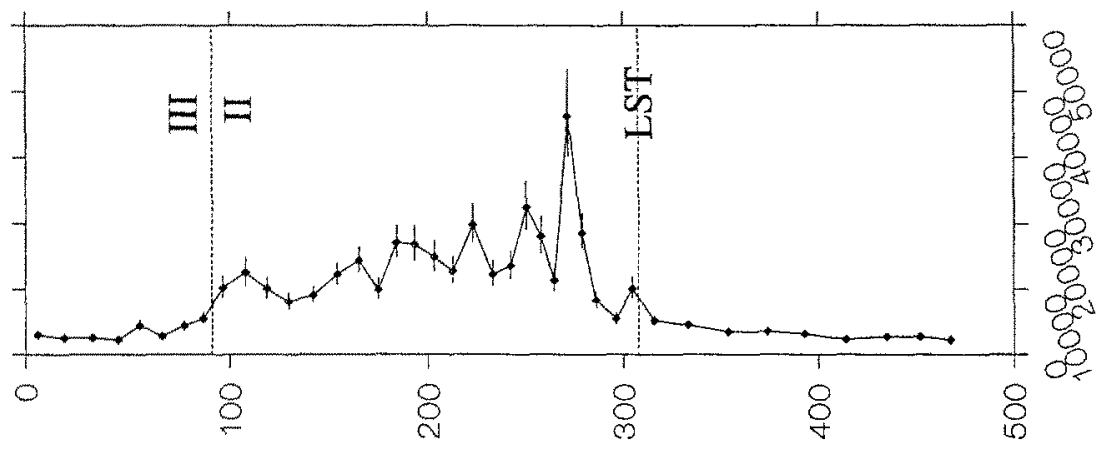

$(8 \exists \wedge \triangleleft \forall \wedge) \exists \bigcirc \forall$ 
were heavily influenced (Baross et al., 1982; Wissmar et al., 1982a, 1982b). However, like the pollen AR, the total diatom AR at Holzmaar also increase after the deposition of the LST (Figs 9 and 10). A similar increase in the absolute number of diatoms has been observed after a modern ashfall which persisted for eight years (Kurenkov, 1966). Palaeolimnological sediment studies often also show a marked increase in the number of diatoms above tephra layers (Barsdate \& Dugdale, 1972; Harper et al., 1986). This may be due to enhanced diatom preservation as a result of an increase in the dissolved silica concentration in the pore water (see e.g. Klee et al., 1993). However, as the diatoms are well preserved above and below the LST, we believe that this effect is not the major reason for the increased AR. According to Van den Bogaard \& Schmincke (1985), the main constituents of the tephra are $\mathrm{SiO}_{2}$ (c. $60 \%$ ), $\mathrm{Al}_{2} \mathrm{O}_{3}$ (c. 20\%) and $\mathrm{Na}_{2} \mathrm{O}$ (c. $10 \%$ ). The increase in overall diatom AR may therefore be explained as a result of the high silica input from the glass particles of the tephra. Furthermore, the $78 \mathrm{~mm}$ thick tephra layer is likely to have reduced the chemical exchange at the sediment-water interface and may therefore have affected the recycling of nutrients from the sediment. This effect, in connection with higher $\mathrm{Si}$ concentrations, could explain the short-lived changes in diatom assemblages (i.e. DAZ D - $1 \mathrm{a}_{2}, 17$ varves, and D-1 $\mathrm{a}_{3}, 29$ varves) before the system returned to its original condition (see Kilham, 1971).

Although benthic organisms should, in theory, be affected most by tephra deposition, this seems not to be the case at Holzmaar (Figs 6 and 7). Periphytic diatoms and mainly the sum of all Fragilaria species show significantly increased accumulation rates for at least 60 years after the LST (i.e. in D- $1 a_{2}$ and D$1 a_{3}$ ). As the core was taken from the deepest part of the basin, planktonic taxa (Stephanodiscus parvus, Cyclotella spp.) are most prominent. The development of these planktonic assemblages can only be directly affected if the tephra stays in suspension for a long time by, for example, water movement which would resuspend and redistribute tephra material from the littoral zone of the lake. However, this is not very likely as no significant amounts of tephra particles were detected in the annual layers above the LST during microstratigraphical thin-section analysis. Moreover, the absolute amount of planktonic diatoms remains constant after the deposition of the LST (Fig. 10).

Both the pollen and diatom stratigraphies suggest that the impact of the eruption on the environment at Holzmaar (corresponding to $\mathrm{P}-1 \mathrm{~b}$ and $\mathrm{D}-1 \mathrm{a}_{2}$ ) was very short, in the order of 10-20 years maximum (Fig. 4). Other biostratigraphical studies associated with tephra horizons have not shown any substantial effect of ashfall on terrestrial vegetation (e.g. Tsukada, 1972; Leopold et al., 1982; Lotter \& Hölzer, 1989, 1994; Newnham \& Lowe, 1991; Lotter \& Birks, 1993; Hall et al., 1994; Birks, 1994), whereas the diatom assemblages have changed in some lakes (e.g. Edmondson, 1984; Harper et al., 1986; Abella, 1988; Lotter \& Birks, 1993; Hickman \& Reasoner, 1994). However, the sampling intervals of most of these studies are rather coarse and the stratigraphical records are therefore only registering long-term changes.

An interesting feature is revealed by the AR of both pollen and diatoms (Fig. 10). Before the deposition of the LST, the values for both groups are rather low but stable. After the perturbation caused by the deposition of the LST both systems show higher, more variable AR. After this perturbation phase the AR again attain a phase of stability until the onset of the Younger Dryas biozone (III). After the LST deposition, the AR of periphytic diatoms and Fragilaria species mainly fluctuate for a period of $c .60$ varves, whereas in the pollen assemblage it is mainly the herbaceous taxa that react over the same time period. The similar duration of this phase of instability suggests a common cause. This may have been the effect of, for example, redeposition processes in the littoral part of Holzmaar. However, as the fluctuations in AR are not synchronous between the pollen and diatom stratigraphies (Fig. 10), their cause may originate from outside the hydrological catchment. In comparison with other studies of volcanic effects, this duration seems too long to reflect an unambiguous climatic change. In a floating pine chronology, which covers the time-span between $c .11300$ and 10800 radiocarbon years B.P., Kaiser $(1989,1991)$ attributes a $c .12$ year decrease in tree-ring width to the effect of the Laacher See eruption. Other examples of tree-ring depressions over 10-15 years after volcano eruptions have been detected by Baillie \& Munro (1988) and Baillie (1994). Ash coating of trees cannot be the cause for these depressions as Mack (1981) showed that this coating is largely washed off during rainfall. However, this depression in tree growth may be explained by aerosols and fine tephra particles that have been transported into the stratosphere. Consequently, they can diffuse or even block the solar energy reaching the Earth for some years and thus lower the temperature for some time (Baillie \& Munro, 1988). It is possible that the increased variability of the pollen and diatom AR after the LST deposition may have 
resulted, in part at least, from climatic changes following the Laacher See volcanic eruption.

Younger Dryas

The response of the terrestrial vegetation to the climatic cooling at the onset of the Younger Dryas (i.e the transition from P-2a to P-2b, see Figs 5 and 7) occurred 216 varves after the deposition of the LST. This time-span correlates well with results from other studies in laminated sediments from Switzerland ( 210 220 yr: Lotter, 1991; Hajdas et al., 1993) and northern Germany (188-204 yr: Merkt in Kaiser, 1993). Dendrochronological data from Switzerland (Kaiser, 1989, 1991) suggest a time period estimated to be at least 195 years between the eruption of the Laacher See volcano and the end of the Allerød Interstadial. This transition is not only evidenced in the pollen percentages (Fig. 5) but also in the absolute values (Figs 8 and 10): the tree AR (mainly Pinus, but also Betula and Salix) decreased steeply, whereas the values of the NAP AR remained at a broadly constant level. These relatively stable NAP values suggest that the density of the pine-birch woodland may have been more or less the same as it was during the Allerød biozone (II), but that the flowering of pine and other trees might have been inhibited due to climatic change in the Younger Dryas.

The transition from $D-1 b$ to $D-2$ occurs 205 varves after the deposition of the LST. It is mainly characterized by a decline in planktonic taxa (especially Stephanodiscus parvus, see Fig. 6) and a steady increase of Fragilaria spp. (mainly $F$. brevistriata). This can be evidenced in both the percentage (Figs 6 and 7) and AR values (Fig. 9). The dominance of small Fragilaria species is characteristic for the late-glacial history of many lakes in Europe and North America (e.g. Round, 1957; Haworth, 1976; Rawlence, 1988). Several hypotheses for the lack of planktonic species and the dominance of these periphytic Frag. ilaria species have been put forward: for example, a long ice cover of the lake can result in only the littoral part being available for algae to live (Smol, 1983, 1988) and/or an increased nutrient input may result from soil erosion. High light penetration in an oligotrophic lake as well as a lake level lowering can also lead to assemblages dominated by benthic Fragilaria species. According to the other constituents of the diatom assemblage a trend towards oligotrophic conditions in the lake can be excluded, whereas a lowering of the lake level due to changes in the precipitation patterns is a hypothesis that should be considered. Several investigations in the Alps, however, indicate a wet first part and a dry second part of the Younger Dryas (see e.g. Lotter et al., 1992a). Furthermore, neither the lithology (Table 2, Fig. 3) nor the diatom assemblages (Fig. 6) in PAZ D-2 give any indications for shore erosion and associated reworking of littoral sediments and diatoms.

The change in the diatom flora at the time of the Allerød-Younger Dryas transition occurs one sample (i.e. 11 varves) earlier than in the pollen assemblages. Assuming the same environmental trigger, the duration of this lag-phase between the terrestrial and the aquatic system seems very short as we would expect the aquatic system to react substantially earlier than the terrestrial system. However, no lag is evident if the cross-correlation (Green, 1981, 1982) between the sum of Fragilaria spp. and the NAP sum is calculated. This more or less synchronous behaviour of terrestrial pollen and diatoms contradicts the classical concept of the different reactions of terrestrial and aquatic vegetation in relation to climate change (e.g. Iversen, 1964; Wright, 1984). However, a comparable synchronous behaviour of aquatic and terrestrial systems has been observed in northern Canada (MacDonald et al., 1993) as well as in many combined studies of pollen and oxygen isotopes from the Alps (e.g. Lotter et al., 1992a), where the major $\delta^{18} \mathrm{O}$ shifts are assumed to reflect continental climatic change without any lag phase. Both pollen stratigraphy and $\delta^{18} \mathrm{O}$ changes closely parallel each other. It thus seems likely that the onset of change in the diatom record at Holzmaar may reflect the crossing of a critical ecological and/or climatic threshold associated with the Allerød-Younger Dryas transition.

\section{Pollen-diatom patterns of variation}

The summary percentage curves of pollen and diatom life-forms, especially the curves of NAP and of the Fragilaria spp., show very similar patterns (Fig. 7), suggesting a common controlling factor Crosscorrelation analysis (Green, 1981, 1982) of the NAP and the sum of Fragilaria spp. at lags of $0,1,2, \ldots 7$ samples shows the highest correlation (0.74) at a lag of 0 .

The major patterns of variation in the diatom- and pollen-stratigraphical data were summarized by means of principal components analysis (PCA). The percentage data-sets were transformed to square roots prior to PCA of the variance-covariance matrix between variables using a correlation biplot scaling (Ter Braak, 
1987, 1990), whereas the AR data were transformed to $\log _{e}(y+1)$ prior to PCA. The results are summarised in Table 6.

PCA axis 1 of both the diatom and pollen percentage data represent over $45 \%$ of the total variance in the two data sets and are 6.4 (diatoms) and 2.7 (pollen) times larger than PCA axis 2, suggesting that the major underlying patterns of variation in these two data sets are reflected by PCA axis 1 only. When the sample scores are plotted against sample age (see Fig. 11) for the two data-sets, a clear correspondence in the PCA scores emerges with the two data-sets closely paralleling each other in terms of shifts in the sample PCA scores. Cross-correlation analysis of the two sets of PCA axis 1 scores shows that the highest correlation $(0.79)$ occurs at a lag of 0 , indicating a close and significant parallelism between the major stratigraphical patterns of variation in the two percentage data-sets.

When expressed as AR, the pollen and diatom data have a less dominant PCA axis 1 (Table $5 ; 36.7 \%$ and $31.8 \%$, respectively) that is only two times larger than PCA axis 2. There is a much poorer correspondence between the sample scores on PCA axis 1 than for the percentage data. Cross-correlation analysis shows no significant cross-correlation except at a lag of 7 samples. With a short time series such as this ( 40 samples), a statistically significant correlation at a lag of 7 is unlikely to have any ecological significance. We conclude that there is a strong similarity in the major patterns of variation, as captured by PCA, in the diatom and pollen data when expressed as percentages but not when they are expressed as AR. This is mainly due to the inherent noise in the AR data sets originating from, for example, different population dynamics as well as taphonomic processes. This noise is greatly reduced when the data are transformed to percentages.

\section{Rates of change}

Rates of change in the diatom and pollen data-sets were estimated for the percentage data as chord distance (=Euclidean distance of square-root transformed data; Prentice, 1980) per 10 years and for the $\left(\log _{e} y+1\right)$ transformed AR data as Euclidean distance per 10 years. No interpolation or smoothings were used (cf. Grimm \& Jacobson, 1992). The rates of change shown in Fig. 12 are thus simply the chord distance or Euclidean distance between adjacent pairs of samples standardised to take account of the different time intervals between adjacent samples (Bennett et al., 1992; Lotter et al., 1992c). The problems of estimating rates of change in palaeoecological data are discussed by Lotter et al. (1992c) and Odgaard (1994).

The percentage diatom data show three high rates of change at 258,279, and 296 years, whereas the pollen percentage data only have high rates of change at 265 years. The rate of changes in the AR data are naturally more variable, but both the diatom and pollen AR data show periods of high rate of change beginning at 304 years and ending at about 240 years.

The most striking common pattern in both the pollen and diatom rate-of-change curves with percentage and AR data is the low rate of change before the deposition of the LST. After the LST deposition all curves show a sharp increase indicative of rapid changes between adjacent pollen and diatom assemblages. The common trend in these changes continues for $c .60$ years after the LST and then the curves start to react in a more individualistic way.

\section{Sequence splitting}

The diatom and pollen $\mathrm{AR}$ for individual taxa are analyzed using Walker \& Wilson's (1978) sequencesplitting technique in an attempt to see what taxa show statistically significant changes in their AR and to see when these changes occurred (see Birks \& Line, 1994 for details). Of the 29 diatom taxa analyzed, 23 showed statistically significant binary and/or variance splits, whereas of the 18 pollen taxa examined, 12 showed statistically significant splits. There are clear concentrations or clustering of the significant splits (Fig. 13) between 290 and 308 years (diatoms) and 308 and 324 years (pollen). The null hypothesis of random location of these splits is strongly rejected $(p \leq 0.0002)$ Using the Gardiner \& Haedrich (1978) test for random positioning of boundaries. Interestingly this concentration of splits occurs at or very soon after the deposition of the LST at 308 years, suggesting that AR changes in many terrestrial pollen taxa and in diatoms may have occurred in response to the LST perturbation. In contrast, there are very few statistically significant splits associated with the Allerød/Younger Dryas transition (Fig. 13).

\section{Variance partitioning}

The total variance in the diatom and pollen data-sets, expressed as both percentages and as AR was partitioned into a series of components defined by different sets of external 'predictor' variables (Borcard et al., 1992). All variance partitioning was done with redun- 


\section{POLLEN}
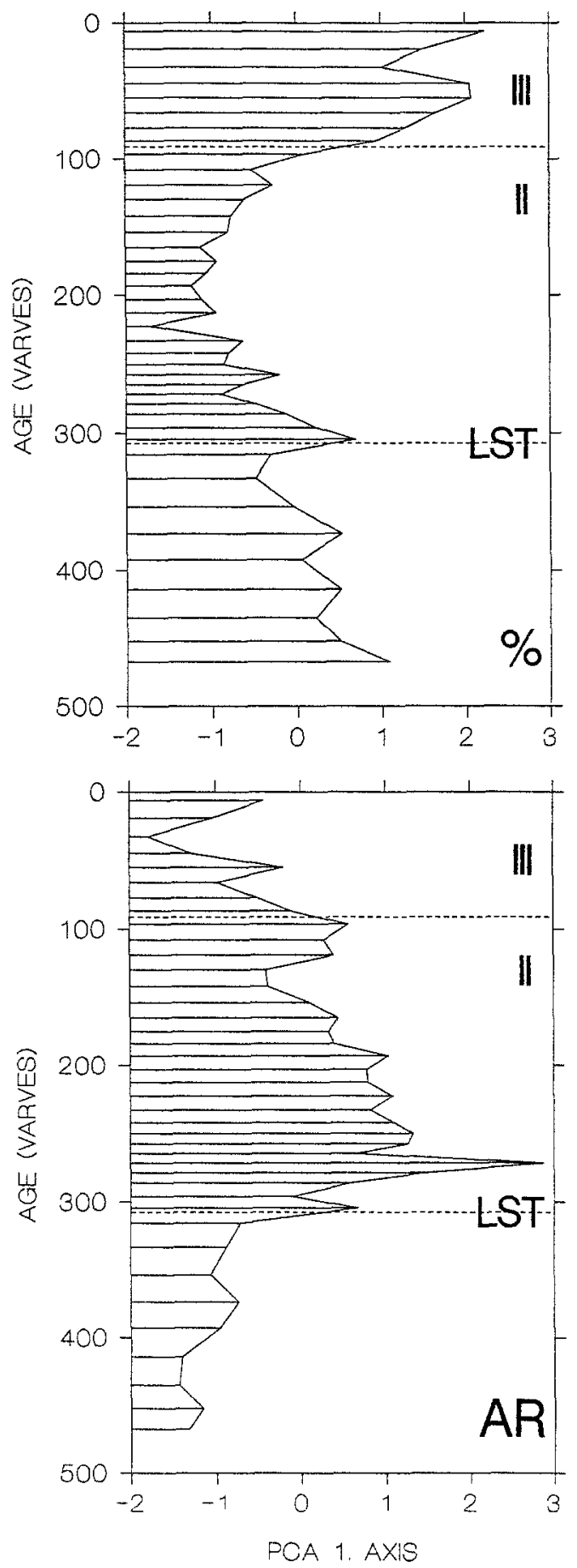

\section{DIATOMS}
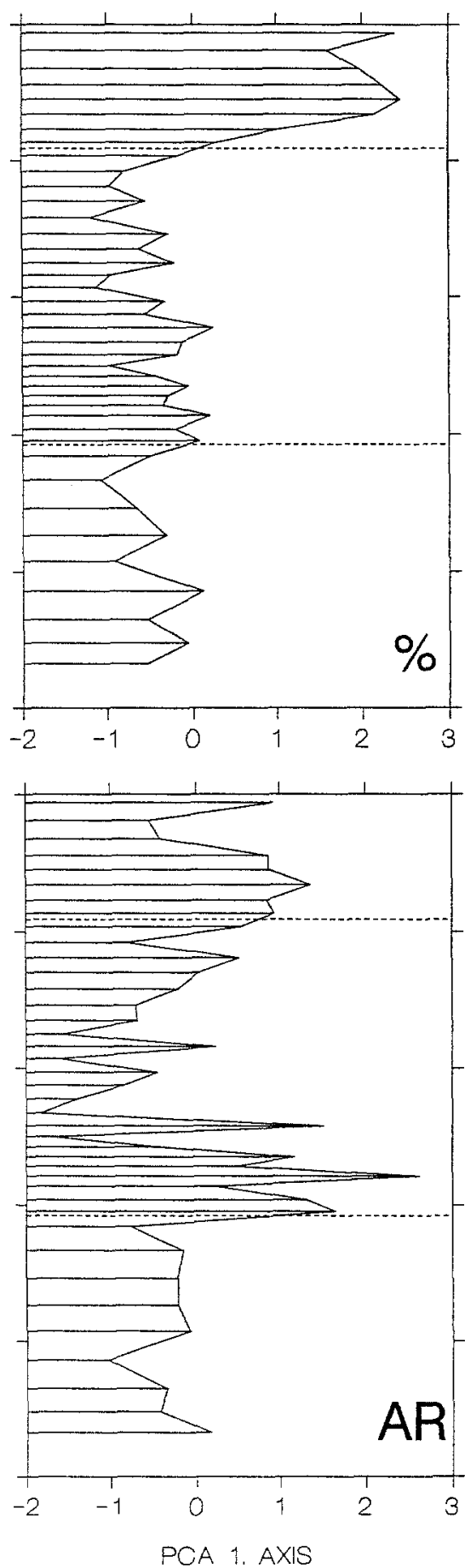

Fig. 11. Sample scores of PCA axes 1 plotted on an age scale for pollen and diatom percentages (\%), and accumulation rates (AR). Horizontal dashed lines mark the location of the Laacher See Tephra ( $307 \mathrm{yr}$, LST) and the transition between the Allerød (II) and Younger Dryas biozones (91 yr, III). 
POLLEN
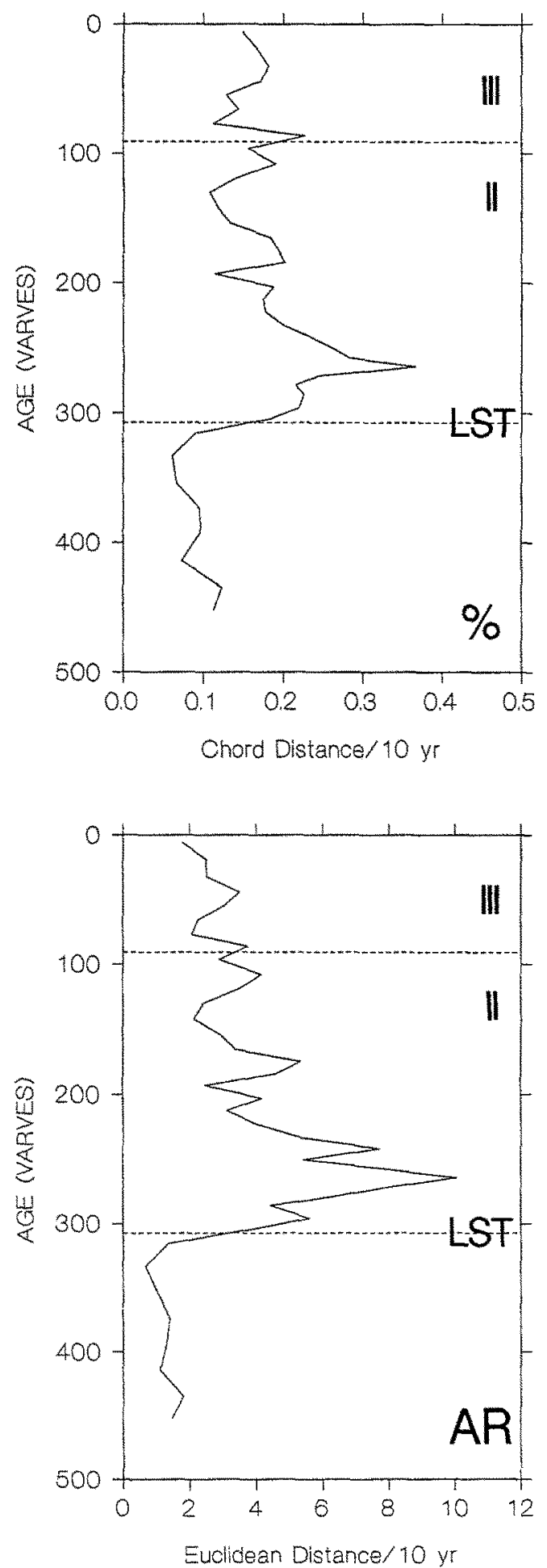

DIATOMS
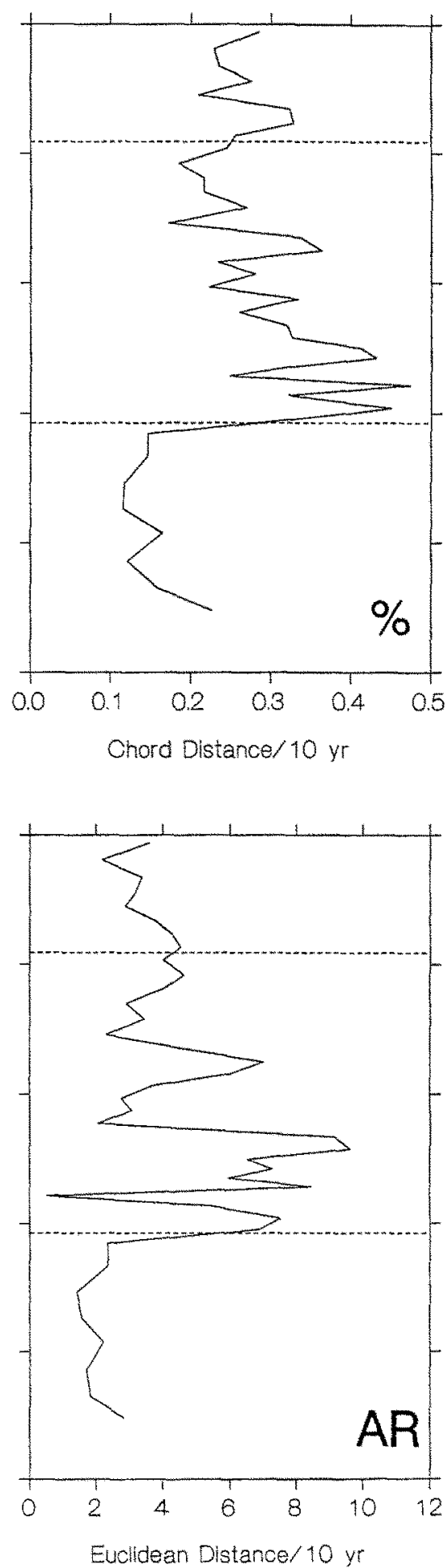

Fig. 12. Rates of change per 10 years for pollen and diatom percentages (\%), and accumulation rates (AR). Horizontal dashed lines mark the location of the Laacher See Tephra (307 yr, LST) and the transition between the Allerød (II) and Younger Dryas biozones (91 yr, II/Im). 
a
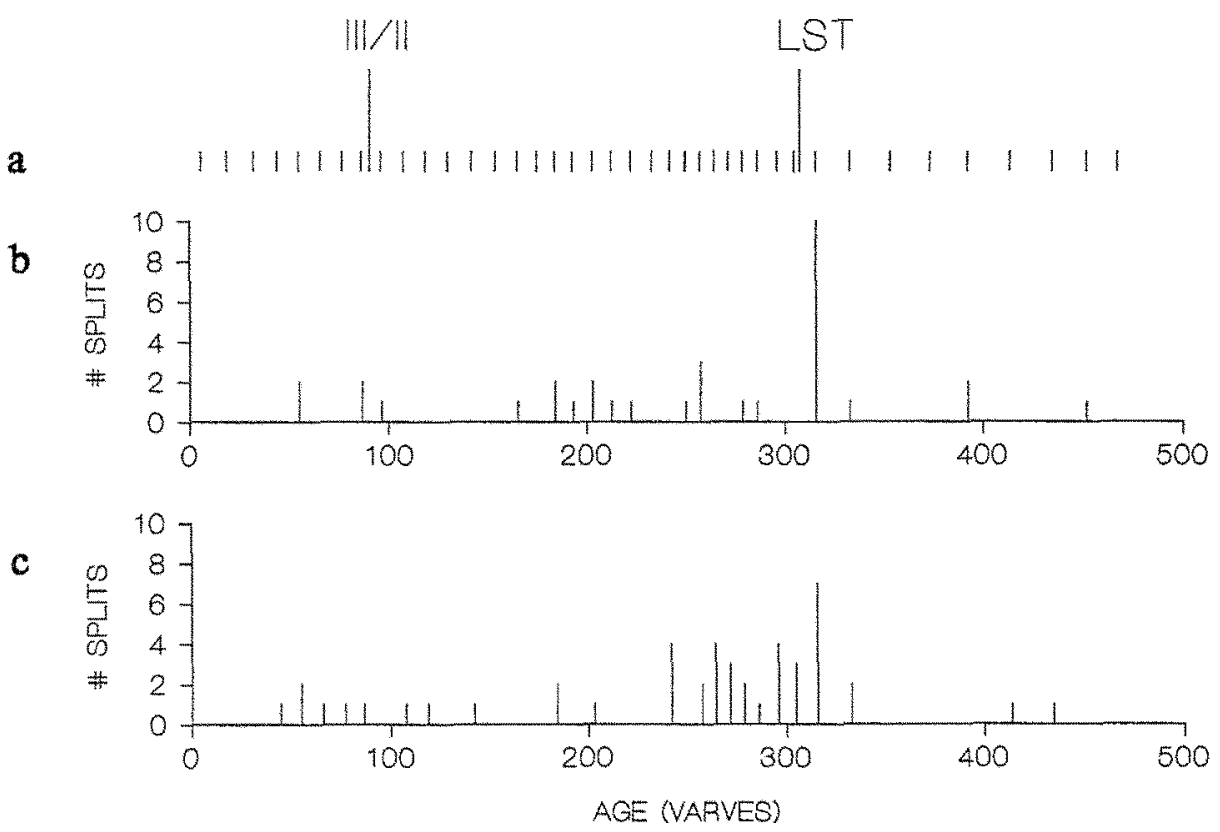

Fig. 13. Sequence splitting results for pollen and diatom accumulation rates (AR). (a) Location of samples, Laacher See Tephra (307 yr, LST), and the boundary between the Allerd and Younger Dryas biozones $(91 \mathrm{yr}, \mathrm{I} / \mathrm{II})$. (b) Location and number of significant splits in the pollen data. (c) Location and number of significant splits in the diatom data. Note that the number of significant splits between time $t$ and time $t+1$ is drawn at time $t$.

dancy analysis (RDA) based on a variance-covariance matrix between variables. The percentage data were transformed to square roots prior to RDA, whereas the accumulation rates were transformed to $\log _{e}(y+1)$ prior to RDA. The variance components estimated are: (1) variance explained by sample age, LST, Younger Dryas or Allerød biozone, and all local pollen or diatom assemblage zones, so-called 'All predictors'; (2) variance explained by sample age only; (3) variance explained by the Younger Dryas or Allerød biozone; (4) variance explained by LST only; and (5) variance explained by local pollen or diatom assemblage zones only. The results are summarized in Table 6.

The RDA model that includes all predictor variables explains over $40 \%$ of the variance in the percentage data and $18-30 \%$ variance in the AR data. Sample age alone is not a statistically significant explanatory variable, indicating the absence of any significant linear temporal trends, whereas assignment of the samples to either the Younger Dryas or the Allerød biozones explains up to $41 \%$ of the variance in the percentage data. These biozones provide statistically significant RDA results for all the data-sets except for pollen AR. In contrast LST, modelled as an exponential process (see Lotter \& Birks, 1993), is a non-significant predictor for all the datasets except for pollen AR.
The local diatom or pollen assemblage zones explain almost as much of the variance in the four data-sets as is explained when all the predictor variables are included in the model. All the RDAs based on local zones are statistically significant.

The main conclusions from these variance partitionings are that the local zonation, not surprisingly, is the most important set of predictor variables, closely followed by the Allerød/Younger Dryas biozones, except for the pollen AR. LST is not a statistically significant explanatory variable for the different data sets (except for the pollen AR) when it is the sole predictor variable. It is, however, statistically significant (Table 4) for all the data-sets except for the diatom percentages when the effects of biozone and sample age are partialled out statistically. In terms of their relative explanatory powers, the local assemblage zones and the Allerød/Younger Dryas biozones are the most important explanatory variables. This is not surprising as the zones are derived from the data. LST by itself is a weak and non-significant explanatory variable (except for the pollen AR, see Table 6). This result suggests, therefore, that the data consist of zones of stability with little additional within-zone stratigraphical change, i.e. a very low additional percentage of the variance in the data is explained by the local zones (except for the 
pollen AR) when compared with the major broad-scale Allerød-Younger Dryas transition (diatom \%: $46.1 \mathrm{vs}$ 41.1; diatom AR 18.4 vs 12.8; pollen \% 39.4 vs 30.4; pollen AR 29.0 vs 10.0 , see also Table 6).

\section{Modelling}

In an attempt to see how well the diatom data could be explained or modelled by the external predictor variables such as biozone, local pollen zones, age, LST, etc., a RDA was done of the diatom percentage data. External predictors included all those used in the variance partitioning plus axes 1-4 of the PCA of the pollen percentage data. These axes were used as a summary of the major stratigraphical patterns in the pollen data (variance represented by axes $1-4$ is $47.1 \%, 17.3 \%$, $5.8 \%$, and $4.8 \%$, respectively). All 13 predictor variables, including pollen PCA axes $1-4$, explain $61 \%$ of the variance in the diatom percentage data. Forward selection of variables was used with 999 unrestricted Monte Carlo permutation tests to find a minimal subset of statistically significant ( $p \leq 0.05$ with Bonferroni correction for multiple simultaneous tests; Cooper, 1968) predictors. Three predictor variables were deemed statistically significant and together they explain $50.2 \%$ of the variance in the diatom percentage data. They are, in order of importance, Younger Dryas biozone $(41 \%, p=0.001)$, pollen PCA axis $1(5 \%, p=0.001)$, and local pollen zone P-1c $(4 \%, p=0.002)$, suggesting that there is a strong response of the diatom relative composition to the Younger Dryas environmental shift and to the major pattern of variation in the pollen percentage data represented by PCA axis 1 .

A similar analysis was done using the diatom AR. Axes $1-4$, based on PCA of the $\operatorname{loge}_{e}(y+1)$ transformed pollen AR data, were included as predictor variables, along with the 13 predictor variables used above. Together they explain $51.2 \%$ of the variance in the diatom AR. Forward selection identified the Younger Dryas biozone $(13 \%, p=0.001)$, LST $(8 \%$, $p=0.003)$, and local pollen zone $\mathrm{P}-1 \mathrm{c}(6 \%, p,=0.004)$ as the only statistically significant predictors of the diatom AR data. These three variables explain $27 \%$ of the total variance in the diatom AR. The empirical modelling results show the importance of the Younger Dryas biozone as an explanatory variable for both the diatom percentage and AR data of terrestrial vegetational changes for the diatom percentage data, and of LST for the diatom AR. The diatom stratigraphy closely parallels climatic, vegetational, and/or tephradepositional changes.

\section{Conclusions}

1. The two perturbations studied were of very different duration and type. The eruption of the Laacher See volcano and the subsequent deposition of its airborne tephra was a drastic but short event that occurred within weeks and had a regional impact, whereas the climatic cooling related to the Younger Dryas happened over decades and was of continental or even global nature. The rates-of-change as well as studies on the impact of both these perturbations on ecosystems can only be assessed by investigations that have a high timeresolution.

2. The eruption of the Laacher See volcano and its tephra deposition show an influence on the pollen assemblages at Holzmaar, both in relative and absolute values. Due to the vicinity of the catchment to the volcano, the birch-pine woodland was affected for a short period of the order of two decades (PAZ P-1b). Subsequently the vegetation recovered and after $c .120$ years (PAZ P-1c) it stabilized again.

The diatom assemblages show only minor changes, suggesting that the tephra deposition did not change the chemistry of the lake significantly. However, after the tephra deposition, diatom population abundances increased substantially, possibly due to the additional silica input.

3. The onset of the Younger Dryas biozone is well marked in the pollen assemblages of Holzmaar. It is characterized in the diatoms by a synchronous change in species composition from the dominant planktonic species Stephanodiscus parvus to assemblages characterized by Fragilaria brevistriata. The diatom succession, mainly when expressed as percentages, but to a minor degree also as AR, is best predicted statistically by the Younger Dryas biozone as well as by the major pollen gradient (represented by the first PCA axis). This strong relationship between the two independent systems suggests climate change to be a common forcing factor. Surprisingly both systems appear to have reacted simultaneously to the changing climatic conditions.

4. Our results suggest that the Holzmaar pollen and diatom records initially reffect stable conditions which were then disturbed by deposition of the Laacher See Tephra. After a phase of recovery both systems again reached a phase of stability before the long-term change associated with the Younger Dryas climatic deterioration changed the assemblages again. The LST perturbation primarily resulted in changes in pollen and diatom AR, whereas the onset of the Younger Dryas 
resulted in changes in both pollen and diatom AR and relative composition.

\section{Acknowledgments}

We should like to thank H. Bolliger, S. Juggins and J. M. Line for their help.

Part of this project was financially supported by Swiss National Science Foundation Project 2031155.91 and German Science Foundation grants DFG Ne 154/21-1 and 21-2.

\section{References}

Abella, S. E. B., 1988. The effect of the Mt. Mazama ashfall on the planktonic diatom community of Lake Washington. Limnol. Oceanogr. 33: 1376-1385.

Alley, R. B. et al. 1993. Abrupt increase in Greenland snow accumulation at the end of the Younger Dryas event. Nature 362: $527-529$

Ammann, $B_{n}$, 1989. Response times in bio- and isotopestratigraphies to Late-Glacial climatic shifts - an example from lake deposits. Ecologae geologica Helvetica 82: 183-190.

Ammann, B. \& K. Tobolski, 1983. Vegetational development during the late-Wuirm at Lobsigensee (Swiss Plateau). Revue de Paléobiologie 2: 163-180.

Ammann, B. \& A. F. Lotter, 1989. Late-Glacial radiocarbon- and palynostratigraphy on the Swiss Plateau. Boreas 18: 109-120.

Baillie, M. G. L., 1994. Dendrochronology raises questions about the nature of the AD 536 dust-veil event. The Holocene 4:212-217.

Baille, M. G. L. \& M. A. R. Munro, 1988. Irish tree rings, Santorini and volcanic dust veils. Nature 332: 344-346.

Baross, J. A., C. N. Dahm, A. K. Ward, M. D. Lilley \& J. R. Sedell, 1982. Initial microbial response in lakes to the Mt St. Helens eruption, Nature 296: 49-52.

Barsdate, R. I, \& R. C. Dugdale, 1972. Effects of volcanic ashfall on chemical and sediment characteristics of two Alaskan lakes. J. Fish. Res. Bd. Can. 29: 229 236.

Battarbee, R.W., 1986. Diatom analysis. In: Berglund, B. E. (ed.), Handbook of Holocene Palaeoecology and Palaeohydrology. J. Wiley \& Sons, Chichester. 527-570.

Battarbee, R. W. \& M. J. Kneen, 1982. The use of electronically counted microspheres in absolute diatom analysis. Limnol. Oceanogr. 27: 184-188.

Bennett, K. D., S. Boreham, M. J. Sharp \& V. R. Switsur, 1992. Holocene history of environment, vegetation and human settlement on Calta Ness, Lunnasting, Shetland. J. Ecol. 80: 241-273.

Birks, H. J. B., 1986. Late-Quaternary biotic changes in terrestrial and lacustrine environments, with particular reference to northwest Europe. In: Berglund, B. E. (ed.), Handbook of Holocene Palaeoecology and Palaeohydrology. I. Wiley \& Sons, Chichester: 3-65.

Birks, H. J. B., 1994. Did Icelandic volcanic eruptions influence the post-glacial vegetational history of the British Isles? Trends in Ecology and Evolution 9: 312-314.

Birks, H. J. B. \& A. D. Gordon, 1985. Numerical Methods in Quaternary Pollen Analysis. Academic Press, London, $317 \mathrm{pp}$.
Birks, H. J. B. \& J. M. Line, 1994. Sequence splitting of pollen accumulation rates from the Holocene and Devensian late-glacial of Scotland. Dissertationes Botanicae 234: 145-160.

Birks, H. J. B. \& A. F. Lotter, 1994. The impact of the Laacher See volcano (11 $000 \mathrm{yr}$ B.P.) on terrestrial vegetation and diatoms. $J$. Paleolimnol. 11: 313-322.

Bogaard Van den, P. \& H.-U. Schmincke, 1985. Laacher See Tephra: a widespread isochronous late Quaternary tephra layer in central and northern Europe. Geological Society of America Bulletin 96: $1554-1571$

Borcard, D, P. Legendre, P. \& P. Drapeau, 1992. Partialling out the spatial component of ecological variation. Ecology 73: 10451055.

Büchel, G., 1984. Die Maare im Vulkanfeld der Westeifel, ihr geophysikalischer Nachweis, ihr Alter und ihre Beziehung zur Tektonik der Erdkruste. PhD Dissertation, University of Mainz.

Charles, D. F., J. P. Smol \& D. R. Engström, 1994. Paleolimnological approaches to biological monitoring. In; Loeb, S. L. \& Spacie, A. (eds.), Biological Monitoring of Aquatic Systems. CRC Press, Boca Raton, Florida. 233-293.

Coope, G. R. 1977. Fossil coleopteran assemblages as sensitive indicators of climatic changes during the Devensian (last) Cold Stage. Phil. Trans. R. Soc. Lond. B 280: 313-340.

Cooper, D.W., 1968. The significance level in multiple tests made simultaneously. Heredity 23:614-617.

Dansgaard, W., H. B. Clausen, N. Gundestrup, C. U. Hammer, S. J. Johnsen, S.J. Kristindottir \& Reeh, 1982. A new Greenland deep ice core. Science 218: 1273-1277.

H. R. Delcourt, P. A. Delcourt \& T. Webb, 1982. Dynamic plant ecology: the spectrum of vegetational change in space and time. Quat. Sci. Rev. 1: 153-175.

Edmondson, W. T., 1984. Volcanic ash in lakes. The Northwest Environmental Journal 1: 139-150.

Eicher, U.\& U. Siegenthaler, 1976. Palynology and oxygen isotope investigations on Late Glacial sediment cores from Swiss lakes. Boreas $5: 109-117$.

Findley, R, 1981. Eruption of Mount St. Helens, National Geographic 159: 3-65.

Firbas, F. 1949. Spät- und nacheiszeitliche Waldgeschichte Mitteleuropas nördlich der Alpen. Vol. 1. Fischer Verlag, Jena, 480 pp.

Firbas, F., 1954. Die Synchronisierung der mitteleuropäischen Pollendiagramme. Danm. Geol. Unders. II, 80: 12-21.

Gardiner, F. P. \& R. L. Haedrich, 1978. Zonation in the deep benthic megafauna. Application of a general test. Oecologia $31: 311-317$.

Green, D. G., 1981. Time series and postglacial forest ecology. Quat. Res, 15: 265-277.

Green, D. G, 1982. Fire and stability in the postglacial forests of southwest Nova Scotia. I. Biogeogr. 9:29-40.

Grimm, E. C., 1987. CONISS: a FORTRAN 77 program for stratigraphically constrained cluster analysis by the methods of incremental sum of squares. Computers and Geosciences 13:13-35.

Grimm, E.C. \& G. L. Jacobson, 1992. Fossil-pollen evidence for abrupt climate changes during the past 18000 years in eastern North America. Climate Dynamics 6: 179-184.

Hajdas, I., S. D. Ivy, I. Beer, G. Bonani, D. Imboden, A. F. Lotter, M. Sturm \& M. Sutter, 1993. AMS radiocarbon dating and varve chronology of Lake Soppensee: 6000 to $12000^{14} \mathrm{C}$ years BP. Climate Dynamics 9: 107-116.

Hall, V. A., J. R. Pilcher \& F. G. McCormac, 1994. Icelandic volcanic ash and the mid-Holocene Scots pine (Pinus sylvestris) decline in the north of Ireland: no correlation. The Holocene 4: 79-83.

Harper, M. A., R. Howorth \& M. McLeod, 1986. Late Holocene diatoms in Lake Poukawa: effects of airfall tephra and changes in depth. New Zeal. J. Mar. Freshwat. Res. 20: 107-118. 
Haworth, E. Y., 1976. Two late-glacial (late Devensian) diatom assemblage profiles from nothern Scotland. New Phytol. 77: $227-256$.

Hickman, M. \& M. A. Reasoner, 1994. Diatom response to late Quaternary vegetation and climate change, and to deposition of wo tephras in an alpine and a sub-alpine lake in Yoho National Park, British Columbia. J. Paleolimnol. 11: 173-188.

Hill, M. O. \& H. G. Gauch, 1980. Detrended correspondence anal$y s i s$, an improved ordination technique. Vegetatio $42: 47-58$.

Hustedt, F, 1954. Die Diatomeenflora der Eifelmaare. Arch. Hydrobiol, $48: 451-496$.

Iversen, J, 1954. The Late-Glacial flora of Denmark and its relation to climate and soil. Danm. Geol. Unders. II, 80: 87-119.

Iversen, J., 1964. Plant indicators of climate, soil, and other factors during the Quaternary. INQUA Report Warsaw 1961, 2: 421-428.

Jacobson, G. L., 1988. Ancient permanent plots: sampling in paleovegetation studies. In: Huntley, B. \& Webb, T. (eds.), Vegetation History. Kluwer, Dordrecht. 3-16.

Jacobson, G. L. \& R. H. W. Bradshaw, 1981. The selection of sites for paleovegetational studies. Quat. Res. 16: 80-96.

Kaiser, K. F., 1989. Late Glacial reforestation in the Swiss Mittelland, as illustrated by Dättnau Valley. In: Rose, J. \& Schliuchter, C. (eds.), Quatemary Type sections: Imagination or reality? Balkema, Rotterdam: 161-178.

Kaiser, K. F., 1991. Tree-rings in Switzerland and other mountain regions: late glacial through Holocene. In: Frenzel, B. (ed.), Evaluation of climate proxy data in relation to the European Holocene. Palaeoclim. Res 6:119-131.

Kaiser, K. F, 1993. Beiträge zur Klimageschichte vom späten Hochglazial bis ins frühe Holozăn, rekonstruiert mit Jahrringen und Molluskenschalen aus verschiedenen Vereisungsgebieten. Ziegler Druck- und Verlags- $A G$, Winterthur, 203 pp.

Kilham, P., 1971. A hypothesis concerning silica and the freshwater planktonic diatoms. Limnol. Oceanogr. 16: 10-18.

Klee, R., R. Schmidt \& I. Müller, 1993. Alleröd diatom assemblages in prealpine hardwater lakes of Bavaria and Austria as preserved by the Laacher See eruption event. Limnologica 23: 131-143.

Krammer, K. \& H. Lange-Bertalot, 1986-1991. Bacillariophyceae. Teil 1-4. Sutsswasserflora von Mitteleuropa. Band 4/1-4. G. Fischer Verlag, Stuttgart.

Kurenkov, I. I., 1966. The influence of volcanic ashfall on biological processes in a lake. Limnol. Oceanogr. $11: 426-429$.

Leopold, E. B., R. Nickmann, J. L. Hedges \& J. R. Ertel, 1982. Pollen and lignin records of late Quaternary vegetation, Lake Washington. Science 218: 1305-1307.

Lotter, A., 1988. Paläoökologische und paläolimnologische Studie des Rotsees bei Luzern. Dissertationes Botanicae 124: 1-187.

Lotter, A. F., 1991. Absolute dating of the late-glacial period in Switzerland using annually laminated sediments. Quat. Res. 35: $321-330$

Lotter, A. F. \& Hölzer, A., 1989. Spätglaziale Umweltverhältnisse im Sudschwarzwald: Erste Ergebnisse paläolimnologischer und paläookologischer Untersuchungen an Seesedimenten des Hirschenmoores. Carolinea 47:7-14.

Lotter, A. F. \& H. J. B. Birks, 1993. The impact of the Laacher See Tephra on terrestrial and aquatic ecosystems in the Black Forest, southern Germany. J. Quat. Sci. 8: 263-276.

Lotter, A. F., U. Eicher, H. J. B. Birks, U. Siegenthaler, 1992a. Lateglacial climatic oscillations as recorded in Swiss lake sediments. J. Quat. Sci. 7: 187-204.

Lotter, A. F., B. Ammann, I. Beer, I. Hajdas \& M. Sturm, 1992b. A step towards an absolute time-scale for the late-glacial: annually laminated sediments from Soppensee (Switzerland). In: Bard,
E. \& Broecker, W. (eds.) The Last Deglaciation: Absolute and Radiocarbon Chronologies. NATO ASI Series I 2: 45-68.

Lotter, A. F., B. Ammann \& M. Sturm, 1992e. Rates of change and chronological problems during the late-glacial period. Climate Dynamics 6: 233-239.

Lotter, A. F. \& A. Hölzer, 1994. A high-resolution late-glacial and early Holocene environmental history of Rotmeer, southern Black Forest (Germany). Dissertationes Botanicae 234: 365-388.

MacDonald, G. M., T. W. D. Edwards, K. A. Moser, R. Pienitz \& J. P. Smol, 1993, Rapid response of treeline vegetation and lakes to past climate warming. Nature $361: 243-246$.

Mack, R. N., 1981. Initial effects of ashfall from Mount St. Helens on vegetation in eastern Washington and adjacent Idaho. Science 213: 537-539.

Maher, L, J, 1981. Statistics for microfossil concentration measurements employing samples spiked with marker grains. Rev. Palaeobot. Palynol. 32: 153-191.

Mangerud, J., S. T. Andersen, B. E. Berglund, B.E. \& J. J. Donner, 1974. Quaternary stratigraphy of Norden, a proposal for terminology and classification. Boreas 3: 109-128.

Newnham, R. M. \& D. J. Lowe, 1991. Holocene vegetation and volcanic activity, Auckland Isthmus, New Zealand. J. Quat. Sci. 6: $177-193$

Odgaard, B. V., 1994. The Holocene vegetation history of northern West Jutland, Denmark. Opera Botanica 123: 1-171.

O'Sullivan, P. E., 1983. Annually-laminated lake sediments and the study of Quaternary environmental changes - a review, Quat. Sci. Rev. 1: 245-313.

Peglar, S.M., 1993. The mid-Holocene Ulnus decline at Diss Mere, Norfolk, U.K.: a year-by-year pollen stratigraphy from annual laminations. The Holocene 3: 1-13.

Pennington, W, 1986. Lags in adjustment of vegetation to climate caused by the pace of soil development: evidence from Britain. Vegetatio 67: 105-118.

Prentice, I. C., 1980. Multidimensional scaling as a research tool in Quaternary palynology: a review of theory and methods. Rev. Palaeobot. Palynol. 31: 71-104.

Prentice, I. C., 1985. Pollen representation, source area, and basin size: towards a unified theory of pollen analysis. Quat. Res. 23: $76-86$.

Prentice, I. C., 1988. Records of vegetation in time and space: the principles of pollen analysis. In: Huntley, B. \& Webb, T. (eds.), Vegetation History. Kluwer, Dordrecht. 17-42.

Rawlence, D. J., 1988. The post-glacial diatom history of Splan Lake, New Brunswick. J. Paleolimnol. 1: 51-60.

Roszanski, K., T. Goslar, M. Dulinski, T. Kuc, M. F. Pazdur \& A. Walanus, 1992. The late glacial-Holocene transition in Central Europe derived from isotope studies of laminated sediments from Lake Gosciaz (Poland) In: Bard, E. \& Broecker, W. (eds.) The Last Deglaciation: Absolute and Radiocarbon Chronologies. NATO ASI Series I $2: 69-80$.

Round, F. E., 1957. The late-glacial and post-glacial diatom succession in the Kentmere valley deposit. New Phytol. 56: 98-126.

Saarnisto, M. 1986. Annually laminated lake sediments. In: Berglund, B. E. (ed.), Handbook of Holocene Palaeoecology and Palaeohydrology. J. Wiley \& Sons, Chichester: 343-370.

Schneider, R. \& K. Tobolski, 1985. Lago di Ganna - Late-Glacial and Holocene environments of a lake in the southern Alps. In: Lang, $G$. (ed.), Swiss lake and mire environments during the last 15000 years. Dissertationes Botanicae 87: 229-271.

Sissons, J. B., 1979. The Loch Lomond Stadial in the British Isles. Nature 280: 199-203.

Smol, J. P., 1983. Paleophycology of a high arctic lake near Cape Herschel, Ellesmere Island. Can. J. Bot. 61: 2195 2204. 
Smol, J. P., 1988. Paleoclimate proxy data from freshwater arctic diatoms, Verh. int. Ver Limnol. 23: 837-844.

Straka, H., 1961. Pollenanalytische Untersuchungen spätglazialer Ablagerungen aus zwei Maaren westlch Gillenfeld (Vulkaneifel). Pollen Spores 3: 275-302.

Straka, H., 1975. Die spätquartäre Vegetationsgeschichte der Vulkaneifel. Beiträge zur Landespflege in Rheinland-Pfalz, Beiheft 3: $1-163$.

ter Braak, C. J. F. 1986. Canonical correspondence analysis: a new eigenvector technique for multivariate direct gradient analysis. Ecology 67: 1167-1179.

ter Braak, C. J. F. 1987. CANOCO - a FORTRAN program for canonical community ordination by [partial] [detrended] [canonical] correspondence analysis, principal components analysis and redundancy analysis. TNO Institute of Applied Computer Science, Statistics Dept., Wageningen, Report 87ITI A 11: 1-95.

ter Braak, C. J. F., 1990. Update notes: CANOCO version 3.10. Agricult. Math. Group, Wageningen, $35 \mathrm{pp}$.

ter Braak, C. J. F. \& I. C. Prentice, 1988. A theory of gradient analysis. Advances in Ecol. Res. 18: 271-317.

Tobolski, K., 1985. Plant macrofossils from Lobsigensee. In: Lang, G. (ed.), Swiss lake and mire environments during the last 15000 years. Dissertationes Botanicae 87: 140-143.

Troels-Smith, J. 1955. Characterization of unconsolidated sediments. Danm. Geol. Unders. IV, 3: 1-73.

Tsukada, M., 1972. The history of Lake Nojiri, Japan. Connecticut Academy of Arts and Sciences Transactions 44: 339-365.

Usinger, H., 1982. Pollenanalytische Untersuchungen an spätglazialen und präborealen Sedimenten aus dem Meerfelder Maar (Eífel). Flora 172: 373-409.
Usinger, H., 1984. Pollenanalytische Untersuchungen zum Alter des Meerfelder Maares und zur Vegetationsentwicklung in der Westeifel während der ausklingenden Eiszeit. In; irion, $G$. \& J. F. W. Negendank (eds): Das Meerfelder Maar. Counier Forschungsinstitut Senckenberg 65: 49-66.

Walker, D. \& S. R. Wilson, 1978. A statistical alternative to the zoning of pollen diagrams. J. Blogeogr. 5: 1-21.

Welten, M., 1982. Vegetationsgeschichthiche Untersuchungen in den westlichen Schweizer Alpen: Bern - Wallis. Denkschr. Schweiz. Naturf. Ges. 95: 1-104.

Wissmar, R. C., A. H. Devol, A. E. Nevissi \& J. R. Sedell, 1982a. Chemical changes of lakes within the Mount St. Helens blast zone. Science 216:175-178.

Wissmar, R. C., A. H. Devol, J. T. Staley \& J. R. Sedell, $1982 b$. Biological responses of lakes in the Mount St. Helens blast zone. Science 216: 178-181.

Wright, H. E., 1984. Sensitivity and response time of natural systems to climatic change in the late Quaternary. Quat. Sci. Rev. 3: 91131.

Zolitschka, B., 1990. Spătquartäre jahreszeitlich geschichtete Seesedimente ausgewähter Eifelmatre. Documenta naturae 60 : $1-226$.

Zolitschka, B., B. Haverkamp \& J. F. W. Negendank, 1992. Younger Dryas oscillation - varve dated microstratigraphic, palynological and palaeomagnetic records from Lake Holzmaar, Germany. In: Bard, E. \& Broecker, W. S. (eds.), The Last Deglaciation. NATO ASI Series I 2: 81-101. 